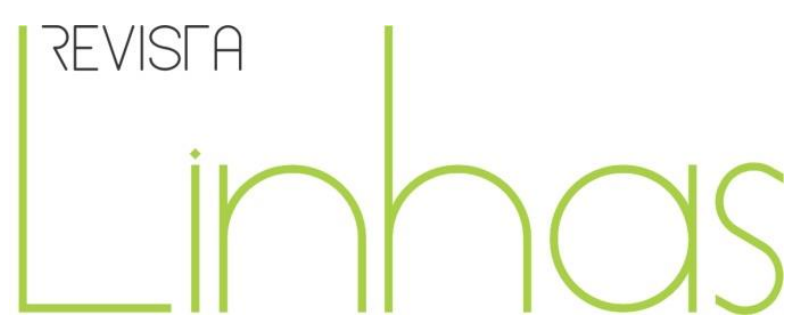

\title{
Os paradoxos da liberdade no pensamento antropológico e político de Rousseau ${ }^{1}$
}

\begin{abstract}
Resumo
A palavra Liberdade (Liberté) está de tal modo presente nos escritos de Rousseau que dessa insistência se pode inferir a importância desse tópico na estruturação do pensamento político do filósofo. E, todavia, devido à sua polissemia e à grande diversidade dos contextos em que ocorre, nada ele tem de convencional e óbvio, apresentando-se antes de forma paradoxal, dando azo a interpretações diametralmente opostas a respeito do sentido e do alcance da proposta política do autor de O Contrato Social. Devem-se tais interpretações divergentes a contradições ou ambiguidades do pensamento do filósofo, que gosta de inventar paradoxos? Ou devem-se antes à natureza do próprio problema da existência política, que talvez não admita solução definitiva, pois não se trata nele apenas de um paradoxo do pensamento, mas sim de um paradoxo realmente inscrito na própria condição social do homem? Assim, o propósito do ensaio é contribuir para a elucidação da polissémica noção de liberdade do filósofo genebrino e desse modo também para sugerir uma resposta à questão relativa ao sentido da sua proposta de solução do problema político.
\end{abstract}

Palavras-chave: Liberdade. Paradoxo. Contrato Social. Vontade Geral. Voluntarismo.

\section{Para citar este artigo:}

DOS SANTOS, Leonel Ribeiro. Os paradoxos da liberdade no pensamento antropológico e político de Rousseau. Revista Linhas. Florianópolis, v. 18, n. 38, p. 304-343, set./dez. 2017.

DOI: $10.5965 / 1984723818382017304$

http://dx.doi.org/10.5965/1984723818382017304

${ }^{1}$ Optou-se por manter a grafia da língua nativa (Língua Portuguesa - Portugal).

\author{
Leonel Ribeiro dos Santos \\ Universidade de Lisboa - \\ Portugal \\ leonelrs@netcabo.pt
}




\title{
Paradoxes of Freedom in Rousseau's anthropological and political Thinking
}

\begin{abstract}
Freedom / Liberty (Liberté) is a word so present in Rousseau's writings, that we can say that is no more insistent and important topic there. And yet, because of its polysemy and the great diversity of contexts in which it occurs, it has nothing from conventional and obvious, giving rise to diametrically opposed interpretations regarding the meaning and scope of the political proposal of the author of The Social Contract. So, we can ask: are such interpretations due to real contradictions or ambiguities of the Genevan philosopher, who likes to invent paradoxes? Or are they due to the nature of human political existence itself, which perhaps does not admit a definitive solution, because the paradoxes are really engraved in the social condition of man? Thus, the aim of this essay is to contribute to the elucidation of Rousseau's notion of freedom, and thereby also to suggest an answer to the question concerning the meaning of his proposed solution to the political problem of human societies.
\end{abstract}

Keywords: Freedom / Liberty. Paradox. Social Contract. General Will. Voluntarism. 
"O filósofo vive de problemas, como o homem vive de alimentos. O que o tempero é para os alimentos, é o paradoxo para os problemas."

(Novalis, Philosophische Schriften, Darmstadt: WBG, 1981, Bd.2, p. 561)

"La liberté, c'est tout Rousseau."

(Edna Kryger, La notion de liberté chez Rousseau et ses répercussions sur Kant, Paris : Nizet, 1979, p. 9.)

\section{1 - Rousseau, «um homem de paradoxos»}

Jean-Jacques Rousseau, seja como homem, como escritor ou como pensador, é ele próprio um problema de que a literatura sobre ele se tem ocupado. Mas é claro que, para além do problema do homem e do escritor, há o problema do significado da sua obra, em particular da sua obra de pensador político: Qual a verdadeira intenção de Rousseau? Há unidade, continuidade e coerência no seu pensamento? ${ }^{2}$

Estas perguntas justificam-se, na medida em que tal intenção, coerência e unidade parecem ser desmentidas pelo desconcerto das interpretações, não raro apaixonadas, que se têm sucedido, sem uma decisão final à vista. No que concerne ao tema que aqui nos ocupa - a ideia de liberdade -, todas elas podem invocar em seu apoio declarações explícitas do filósofo. Assim, podemos ter: 1) ora um Rousseau hobbesiano, defensor incondicional da soberania como algo absoluto, indivisível e inalienável; 2) ora um Rousseau lockiano, tendencialmente liberal e mesmo individualista; 3) ora um Rousseau republicano, que põe em evidência a liberdade como autonomia e a capacidade dos cidadãos para instituírem as leis a que eles próprios se submetem, na linha do que virá a ser proposto por Kant, filósofo cujo pensamento ético e político se inspirará largamente no pensamento do citoyen de Genève; 4) ora, por fim, um Rousseau precursor das doutrinas do totalitarismo estatista, que parece propor a imposição da lei do todo

\footnotetext{
${ }^{2}$ O presente texto é uma versão ampliada do que, sob o título «A ideia de liberdade no pensamento de Rousseau", foi publicado em Ernesto Castro Leal (Org.), República e Liberdade, Lisboa : CHUL, 2011, pp.149179. Todas as traduções de textos citados são do autor deste ensaio.
} 
coletivo - a «volonté générale» - aos indivíduos, negando-lhes aparentemente aquela liberdade que, por outro lado, parecia defender e prometer-Ihes. ${ }^{3}$

Se é certo que as divergências interpretativas não podem ser de todo anuladas, elas podem, contudo, ser atenuadas e matizadas, nomeadamente, caso se tenha em conta não só a complexidade da obra do filósofo como também alguns aspetos metodológicos da sua abordagem. Em primeiro lugar, o que se poderia chamar o estatuto epistémico do discurso político do filósofo genebrino, que nos obriga, em cada caso e em cada obra, a averiguar o plano em que o seu autor se implanta: trata-se de um programa para ser executado efetivamente ou de uma conjetura hipotética? De facto, mais do que uma vez Rousseau expõe o seu pensamento político e social como se procedesse a uma experiência mental. Com efeito, confessa:

Uma vez que os acontecimentos que me proponho descrever puderam acontecer de muitas maneiras, só posso decidir-me pela escolha mediante conjeturas; mas as conjeturas se tornam razões quando são as mais prováveis que se podem tirar da natureza das coisas. ${ }^{4}$

Até a sua obra Émile, ou de l'Éducation deve ser lida nesse registo, não como um «verdadeiro tratado de educação», mas como uma experiência imaginária do que seria uma educação de um «élêve imaginaire», feita a sós e em continuidade com o seu preceptor e ao simples fio da natureza, tendo por pressuposto o princípio da bondade

\footnotetext{
${ }^{3}$ Estas desconcertantes contradições viriam a ser apontadas por Benjamin Constant, que assim escrevia: «La métaphysique subtile du Contrat social n'est propre, de nos jours, qu'à fournir des armes et des prétextes à tous les genres de tyrannie, à celle d'un seul, à celle de plusieurs, à celle de tous, à l'oppression constituée sous des formes légales, ou exercées par des fureurs populaires. [...] Qui signifient des droits dont on jouit d'autant plus qu'on les aliène plus complètement? qu'est-ce qu'une liberté en vertu de laquelle on est d'autant libre, que chacun fait plus complètement ce qui contrarie sa volonté propre ? Les fauteurs du despotisme peuvent tirer un immense avantage des principes de Rousseau.» Benjamin Constant, De l'esprit de conquête et de l'usurpation dans leurs rapports avec la civilisation européenne (1814), in: Écrits politiques, Paris: Gallimard, 1997, pp.211-212. Veja-se também: J. L. Talmon, The Origins of Totalitarian Democracy, London: Secker \& Warburg, 1952; J. W. Chapman, Rousseau - Totalitarian or Liberal?, New York: Columbia University Press, 1956. É impossível dar conta mesmo só da literatura (livros ou artigos) expressamente dedicada ao tema da Liberdade em Rousseau, sendo que esse tópico é incontornável seja qual for o ângulo por onde se aborde o pensamento político do filósofo. Destaco apenas a que é visada ou usada na economia deste ensaio: de Hannah Arendt, de Benjamin Constant, de Edna Kryger, de John Plamenatz, de Mathew Simpson, de Quentin Skinner, de Otto Vossler (ver Referências).

${ }_{4}$ «J'avoue que les événements que j'ai à décrire ayant pu arriver de plusieurs manières, je ne puis me déterminer sur le choix que par des conjectures; mais outre que ces conjectures deviennent des raisons, quand elles sont les plus probables qu'on puisse tirer de la nature des choses.» Discours sur l'origine et les fondements de l'inégalité (doravante : Discours), Paris : Gallimard, 1965, p. 85.
} 
natural do homem, mas que o filósofo sabe bem ser irrealizável na prática. ${ }^{5} \mathrm{E}$, sendo assim, as noções de «natureza», «estado de natureza», «contrato social» e «vontade geral» não deveriam ser consideradas como categorias descritivas, mas como pontos de vista para apreciar a condição histórica efetiva dos homens e para desenhar um quadro ideal de referência que permitisse melhor equacionar o problema da condição humana. Daí decorreria o carácter essencialmente conjetural ou até ficcional do pensamento político de Rousseau, aspeto de que o próprio revela ter consciência, ao sublinhar o que distingue a sua atitude teórica da dos outros filósofos políticos. Estes, segundo diz, costumam partir dos factos para estabelecer o Direito, ao passo que ele parte do Direito para julgar os factos. É significativo que diga isso precisamente a propósito do tema que aqui nos ocupa e contra aqueles que, a partir da amplamente documentada constatação descritiva da situação histórica de facto de escravidão e de opressão dos povos ou dos indivíduos, queriam estabelecer e justificar formalmente o direito de se continuar a oprimi-los e a privá-los de liberdade. Eis as suas palavras:

Os políticos fazem sobre o amor da liberdade os mesmos sofismas que os filósofos fizeram acerca do estado de natureza; pelas coisas que veem julgam coisas muito diferentes que não viram, e atribuem aos homens uma propensão natural para a servidão devido à paciência com que aqueles que eles veem suportam a sua servidão, sem pensar que se passa com a liberdade o mesmo que com a inocência e a virtude, das quais só se sente o preço na medida em que dispomos de nós mesmos, e cujo gosto se perde logo que as perdemos. ${ }^{6}$

Deve, por outro lado, ter-se em conta o alto teor retórico do discurso político rousseauano, patente nas oposições e contrastes, nas declarações desconcertantes de um autor que se definia como «un homme à paradoxes» ${ }^{7}$. Mais do que sinais da falta de

\footnotetext{
${ }^{5}$ Lettre à Philibert Cramer, oct. 1764, Jean-Jacques Rousseau, Correspondance Complète, ed. Ralph A. Leigh (Oxford: Voltaire Foundation, 2004), vol. 21, $\mathrm{n}^{\circ} 3564$, p. 248: «Vous dites três bien qu'il est impossible de faire un Émile. Mais je ne puis croire que vous preniez le livre qui porte ce nom pour un vrai traité d'éducation. C'est un ouvrage assez philosophique sur ce principe avancé pour l'auteur dans d'autres écrits que l'homme est naturellement bon. Pour accorder ce principe..."

${ }^{6}$ «Les politiques font sur l'amour de la liberté les mêmes sophismes que les Philosophes ont faits sur l'état de Nature; par les choses qu'ils voyent ils jugent des choses très différentes qu'ils n'ont pas vues, et ils attribuent aux hommes un penchant naturel à la servitude par la patience avec laquelle ceux qu'ils ont sous les yeux supportent la leur, sans songer qu'il en est de la liberté comme de l'innocence et de la vertu, dont on ne sent le prix qu'autant qu'on en joüit soi-même, et dont le goût se perd sitôt qu'on les a perdues.» Discours, p. 110.
}

${ }^{7}$ Lettre à Philopolis, in : Discours, p. 138. 
clareza ou de inconsequência lógica do pensamento, as ambiguidades, as oposições, os contrastes e os paradoxos parecem antes estar ao serviço de uma poderosa retórica da provocação e da sedução. ${ }^{8}$ Mas será que as contradições e os paradoxos estão só no discurso, ou inscrevem-se na coisa mesma de que este trata - a saber, na condição social dos homens -, a que o discurso político do filósofo tenta dar expressão e solução?

Podem aduzir-se sobejos exemplos dessa estratégia retórica. Eis alguns em que se estabelece o contraste, a oposição irredutível entre liberdade e servidão. Como este, logo no início do cap. I de Du Contrat Social (doravante, também sob forma abreviada:CS), onde se lê: «L'homme est né libre, et partout il est dans les fers. Tel se croit le maître des autres, qui ne laisse pas d'être plus esclave qu'eux.» Ou estoutro: «empire et liberté étant deux mots incompatibles... ». ${ }^{9}$

Mas não faltam passagens onde o filósofo faz a fusão de opostos, nomeadamente entre obediência (ou subordinação / submissão) à lei e liberdade, como estas: "l'obéissance à la loi qu'on s'est prescrite est liberté.»" ${ }^{10}$; "quiconque réfusera d'obéir à la volonté générale y sera constraint par tout le corps : ce qui ne signifie autre chose sinon qu'on le forcera d'être libre... " ${ }^{11}$; «assujetir les hommes pour les rendre libres... ». ${ }^{12}$ "Comment se peut-il faire qu'ils obéissent et que personne ne commande ?» ${ }^{13}$ Ou ainda esta, mais filosófica, que identifica liberdade e necessidade: «C'est vous, ô mon maître, qui

\footnotetext{
${ }^{8}$ Kant, nas suas Lições de Antropologia do ano 1784-85 e também nas Reflexões, refere-se ao pensamento antropo-político de Rousseau como sendo os "paradoxos de Rousseau" ou os " 3 paradoxos de Rousseau" (Vorl.ü.Anthropologie, AA 25.2:1419), e ele próprio declara num seu ensaio de meados da década de 80 que, no que toca às coisas humanas, «quase tudo é paradoxo» (darin fast alles paradox ist - Beantwortung der Frage: Was ist Aufklärung?, AA 08:41). Veja-se o meu ensaio «Os "paradoxos de Rousseau" explicados pelo Professor Kant», in: K. B. Basílio, Leonel Ribeiro dos Santos, M. J. Almeida (Orgs.), Jean-Jacques Rousseau: O Homem, a Obra, o Pensamento, Famalicão: CEC/Editorial Húmus, 2014, pp. 25-48. Num outro passo do mesmo Curso de Antropologia de 1784, o Professor Kant desenvolve uma reflexão sobre o tópico do paradoxo ou juízo paradoxal, pondo o acento na sua dimensão de risco e ousadia, pois propõe ideias à primeira vista insensatas que desafiam as ideias feitas e vulgares e nos fazem ver o outro lado das coisas, mas é dessa maneira que se revela a sua fecundidade cognitiva, já que assim se pode chegar à descoberta de novas perspetivas, o que vai acompanhado de uma gratificante experiência estética de prazer no conhecimento: «Weil uns das paradoxe eine Erweiterung unsrer Erkenntniss zeigt so erfreut es uns und ist uns angenhem... Alles Paradoxe giebt uns Eröffnung zu neuen Aussichten.» (Vorl.̈̈.Anth., AA 25.2:1225).

9 Émile ou De l'Éducation (doravante : Émile), texte établi par Charles Wirz présenté et annoté para Pierre Burgelin, Gallimard, Paris, 1969, p. 692. Os sublinhados de texto são nossos.

${ }^{10}$ Du Contrat Social (doravante : CS), I, viii, Garnier-Flammarion, Paris, 1966.

${ }^{11} \mathrm{CS}, \mathrm{I}$, vii.

${ }^{12}$ Economie politique (art. publicado no vol. V da Encyclopédie, 1755), in: The Political Wrtings of J.-J.Rousseau, ed. de C. E. Vaughan, Oxford/New York, 1962, vol. I, p. 245.

${ }^{13}$ Ibidem.
} 
m'avez fait libre en m'apprenant à céder à la nécessité.. ${ }^{14}$ : uma confissão que parece reenviar-nos para o Estoicismo (ou para o Espinosismo!), segundo o qual a verdadeira liberdade consiste em obedecer à ordem necessária da natureza, que é também a ordem imperativa da razão. E talvez seja mesmo esta a mais profunda ideia que Rousseau nos transmite acerca do nosso tema: uma vez perdida, sem recuperação possível, a ordem original da natureza, a solução que resta aos homens é, pela sua vontade e artifício, criarem a ordem convencional do corpo social e inscreverem-se nela incondicionalmente, como se fosse uma nova ordem natural, agora ditada pela razão. E isto muito embora o autor de $O$ Contrato Social declare expressamente que «não é assunto que o ocupe o sentido filosófico da palavra liberdade». ${ }^{15}$

Acrescente-se ainda o gosto pelos extremos alternativos: ou... ou. Rousseau não admite soluções de meio-termo, de mediação ou de compromisso. Constatando não ser possível que os homens, tendo chegado ao estado a que chegaram, possam prosseguir no estado de natureza ou regressar a ele, a solução que se impõe é «desnaturar o homem» por ação do artifício da convenção social voluntária, que é o pacto ou contrato social e das leis que dele emanam, e assim substituir radicalmente o «homem» (homme) natural pelo «cidadão» (citoyen). Para este filósofo, não há continuidade entre natureza e sociedade. A sociedade não é natural ao homem e as formas de sociedade não decorrem da natureza humana, nem são a expressão desenvolvida das potencialidades ou faculdades nela originariamente inscritas. São antes o sintoma de doença, de decrepitude, de degenerescência. Assim o diz sem ambiguidades:

Segundo a minha opinião, a sociedade é natural à espécie humana como a decrepitude o é ao indivíduo e as artes, as leis e os governos estão para os Povos como as muletas para os velhos. ${ }^{16}$

\footnotetext{
${ }^{14}$ Émile, p. 692. Veja-se, no mesmo tom, um outro passo da mesma obra, onde se lê : «Reste à la place que la nature t'assigne dans la chaîne des êtres, rien ne t'en pourra faire sortir ; ne regimbe point contre la dure loi de la nécessité, et n'épuise pas, à vouloir lui résister, des forces que le ciel ne t'a point données pour étendre ou prolonger ton existence, mais seulement pour la conserver comme il lui plaît et autant qu'il lui plaît. Ta liberté, ton pouvoir, ne s'étendent qu'aussi loin que tes forces naturelles, et pas au-delà... (Émile, p. 144).

${ }^{15}$ CS, I,viii : «... le sens philosophique du mot liberté n'est pas ici de mon sujet.» Uma declaração que, quando muito, deve entender-se como circunscrita ao CS, mas não extensível às outras obras do filósofo.

${ }^{16}$ "Selon moi la société est naturelle à l'espèce humaine comme la décrépitude à l'individu, et qu'il faut des arts, des Loix, des Gouvernemens aux Peuples, comme il faut des béquilles aux vieillards.» Lettre à Philopolis, in: Discours, pp. 137-138.
} 
No mesmo registo se deve entender a confissão autobiográfica do final da Sexta Caminhada das Rêveries, onde o autor declara a inadequação da sua pessoal natureza para viver na sociedade civil com todas as exigências e obrigações que esta implica, nestes termos:

eu nunca fui adequado à sociedade civil onde tudo é desconforto, obrigação, dever, e o meu natural independente tornou-me sempre incapaz das sujeições necessárias a quem quer viver com os homens. ${ }^{17}$

Mas, então, para que se dá ele ao esforço de arquitetar a exigente sociedade do contrato social, se a considera impossível de suportar, e se não quer - ou não se reconhece apto para - viver nela?

Por vezes, lendo Rousseau, ficamos com a impressão de que, por detrás de todo o seu engenhoso discurso, o que ele realmente pretende é pôr em evidência a insolubilidade da questão política, mostrar que a existência social dos homens não tem solução garantida, não porque esta solução não seja racionalmente pensável ou possível, mas porque os homens não a suportariam, de tão exigente que é, e acabariam por preferir o jugo dos tiranos e a escravidão à austeridade das leis que lhes garantiriam a liberdade. Como se depreende deste passo de Sobre o governo da Polónia:

Nobre e santa liberdade! Se estas pobres gentes pudessem conhecer-te, se soubessem a que preço se te adquire e se te conserva, se elas sentissem quanto são mais austeras as tuas leis do que o é o jugo dos tiranos; as suas pobres almas, vítimas de paixões que seria necessário abafar, temer-te-iam cem vezes mais do que a servidão; elas fugiriam de ti com horror como de um fardo prestes a esmagá-los. ${ }^{18}$

Esta consideração choca por certo com a explícita declaração do filósofo que revela a sua pretensão de ter encontrado não só a boa equação como até mesmo a

\footnotetext{
${ }^{17}$ «Je n’ai jamais été vraiment propre à la société civile où tout est gêne, obligation, devoir, et que mon naturel indépendant me rendit toujours incapable des assujettissements nécessaires à qui veut vivre avec les hommes.» Les Rêveries du promeneur solitaire, Sixième Promenade, Garnier-Flammarion, Paris, 1964, p. 118.

${ }^{18}$ «Fière et sainte liberté ! Si ces pauvres gens pouvaient te connaître, s'ils savaient à quel prix on t'acquiert et te conserve, s'ils sentaient combien tes lois sont plus austères que n'est dur le joug des tyrans ; leurs faibles âmes, esclaves de passions qu'il faudrait étouffer, te craindraient plus cent fois que la servitude ; ils te fuiraient avec effroi comme un fardeau prêt à les écraser.» Sur le gouvernement de Pologne,in : CEuvres Complètes, Paris: Gallimard, III, p. 974.
} 
solução do problema político da condição humana: «eu creio poder resolver esta questão.» (CS I,i). Mas veja-se, a propósito, a carta a Mirabeau (de 26 de Julho de 1767):

Se infelizmente não for possível encontrar esta forma de regime <que coloca a lei acima do homem>, e eu confesso-o ingenuamente que creio que não o é, a minha opinião é que se deve passar à outra extremidade, e de um golpe colocar o homem acima da lei tanto quanto possa está-lo; por conseguinte, estabelecer o despotismo arbitrário, e o mais arbitrário que é possível: eu quereria que o déspota pudesse ser Deus. Numa palavra, eu não vejo meio-termo suportável entre a mais austera democracia e o hobbismo mais perfeito: pois o conflito dos homens e das leis, que coloca o Estado numa guerra intestina contínua, é o pior de todos os estados políticos. $^{19}$

Devem ler-se tais declarações como sendo expressão de uma efetiva atitude de ceticismo, ou tão só como provocantes exercícios retóricos de ironia? Em suma, tratandose de Rousseau, temos que fazer aquele exercício que Kant praticava ao lê-lo, confessando ter de dobrar o cuidado para que a beleza da escrita não lhe impedisse o acesso à apreensão da profundidade da mensagem contida nas obras do pensador genebrino. Devemos praticar esse cuidado, mesmo, é claro, que por fim não concordemos com a sua mensagem. Pois uma coisa não se pode negar: Rousseau é um dos mais poderosos e sedutores escritores que alguma vez teve a literatura francesa.

\section{2 - As formas, os paradoxos e as aporias da liberdade}

Tudo em Rousseau parece nascer de um impulso profundo para a liberdade e de um propósito de a assegurar. É como se o filósofo, tendo reconhecido a impossibilidade de continuar na ou de regressar à independência ou liberdade do estado de natureza, quisesse garantir um simulacro dessa liberdade sob a forma de liberdade civil, na sociedade organizada com base na sua doutrina do contrato social, de modo a superar

\footnotetext{
${ }^{19}$ «Si malheureusement cette forme <de régime qui place la loi au-dessus de l'homme> n'est pas trouvable, et je l'avoue ingénument que je crois qu'elle ne l'est pas, mon avis est qu'il faut passer à l'autre extrémité, et mettre tout d'un coup l'homme au-dessus de la loi qu'il peut l'être; par conséquent, établir le despotisme arbitraire, et le plus arbitraire qu'il est possible : je voudrais que le despote pût être Dieu. En un mot, je ne vois point de milieu supportable entre la plus austère démocratie et le hobbisme le plus parfait : car le conflit des hommes et des lois, qui met dans l'État une guerre intestine continuelle, est le pire de tous les états politiques.» Lettre à Monsieur le Marquis de Mirabeau, in: Jean-Jacques Rousseau, Collection complète des Euvres, Genève: Du Peyrou/ Moultou, 1780-1789, vol. 12 (1782), p. 162 (http://www.rousseauonline.ch/Text/lettre-a-monsieur-le-marquis-de-mirabeau.php).
} 
aquela condição do homem que se verifica nas sociedades históricas conhecidas, que exibem uma vasta e diversificada sucessão de formas de escravidão e de opressão dos homens por algum ou alguns dos seus semelhantes. Mas qual é, ao fim de contas, a noção rousseauana de liberdade? Um intérprete, que abordou o tema, acaba concluindo que Rousseau não trouxe nenhuma nova ideia de liberdade, mas deu-nos novas ideias acerca das condições sociais e psicológicas da liberdade. ${ }^{20}$ Talvez John Plamenatz tenha nisso inteira razão e o que acerca da liberdade Rousseau melhor tenha a ensinar-nos seja mesmo o levar-nos a tomar consciência dos paradoxos e aporias que a envolvem. ${ }^{21}$

Para começar, poderíamos tentar averiguar o que pode ter em comum a noção rousseauana da liberdade com a de outros filósofos políticos modernos. De facto, se a ideia de liberdade está no cerne de muitas doutrinas políticas, e é por elas invocada por vezes com grande ênfase, ela não é de modo nenhum unívoca. Vários analistas e intérpretes têm tentado tipificar, classificar e arrumar essas diversas conceções, e fizeram-no em três direções, embora as diferentes categorias por eles identificadas ora se correspondem ora se sobrepõem, pelo menos parcialmente, podendo combinar-se umas com outras. ${ }^{22}$ Houve quem, seguindo um critério histórico-civilizacional, identificasse o que chamou a liberdade dos Antigos (caracterizada pela participação intensa dos cidadãos na vida coletiva da polis e pela redução da vida individual à vida da comunidade, como liberdade do povo ou da república) e a liberdade dos Modernos (caracterizada pelo sentimento incontornável da independência individual, como liberdade do indivíduo ou do cidadão). Tal foi a proposta de Benjamin Constant, nos seus escritos políticos, em particular num Discurso que se tornaria célebre. ${ }^{23}$ Outros, adotando um critério lógicoconceptual, identificaram dois tipos de liberdade: uma, entendida num sentido negativo,

\footnotetext{
${ }^{20}$ «It has been claimed for Rousseau that he offers us a new idea of freedom. I would prefer to say that he offers us new ideas about freedom. I doubt whether we can find in his writings a definition of freedom which is both new and acceptable, but I believe that we can find in them new ideas about the social and psychological conditions of freedom.» John Plamenatz, "Ce qui ne signifie autre chose sinon qu'on le forcera d'être libre» in: M. Cranston and Richard S. Peters (eds.), Hobbes and Rousseau. A Collection of Critical Essays, New York: Anchor Books, 1972, p. 319.

${ }^{21}$ Veja-se: Quentin Skinner, «The Paradoxes of Political Liberty», in: David Miller (ed.), Liberty, Oxford: Oxford University Press, 1991, pp. 183-205.

${ }^{22}$ Para uma visão sinóptica, veja-se: Chandran Kukathas, «Liberty», in: Robert E. Goodin and Philipp Pettit (eds.), A Companion to Contemporary Political Philosophy, Oxford/ Cambridge Mas: Blackwell, 1993, pp. 534547.

${ }^{23}$ Benjamin Constant, «De la liberté des Anciens comparée à celle des Modernes. Discours prononcé à l'Athénée Royal de Paris en 1819", in Écrits Politiques, pp. 589-619.
} 
como ausência de impedimento ou de uma qualquer lei proibitiva que interfira com a atividade do indivíduo; outra, num sentido positivo, como autonomia e autodeterminação do indivíduo que é senhor de si e cuja vida e decisões dependem de si próprio e não de forças externas, sejam elas quais forem, e que, por conseguinte, é responsável pelas suas decisões. Tal a proposta de Isaiah Berlin, num ensaio que igualmente se tornou uma referência clássica a respeito do tema. ${ }^{24}$ Poder-se-ia, por fim, adotar o critério das doutrinas políticas que predominantemente se inspiram no conceito de liberdade. E teríamos então ora uma conceção liberal e tendencialmente individualista de liberdade, que corresponderia à liberdade dos Modernos, segundo a tipologia de Constant, e aproximadamente ao sentido negativo de liberdade, segundo a classificação de Berlin, entendendo-se como uma prerrogativa ou direito do indivíduo e sendo caracterizada pela ausência de interferência e dependendo o índice da liberdade dos indivíduos do maior ou menor silêncio da lei, naquele sentido em que também Hobbes e Locke a entendiam; ora uma conceção republicana de liberdade, entendida como a soberania e autonomia do corpo coletivo e como a submissão dos cidadãos à lei que eles próprios originariamente instauraram mediante o contrato ou à qual deram consentimento pelas suas livres vontades.

Houve historiadores e filósofos políticos da Modernidade que leram nas formas políticas antigas da democracia ateniense e da república romana esta última forma qualificada de liberdade em que os cidadãos obedecem não a uma pessoa, mas à lei. ${ }^{25} \mathrm{E}$ talvez seja para esta noção democrática e republicana de liberdade dos antigos Gregos e Romanos que pende o pensamento de Rousseau enquanto pensamento propriamente político, vendo neles, ao contrário do que acontecia nas nações modernas, povos que por nada estavam dispostos a alienar a sua responsabilidade pública e «cuja essencial tarefa

\footnotetext{
${ }^{24}$ Isaiah Berlin, «Two Concepts of Liberty» (1958),in: Idem, Four Essays on Liberty, Oxford: Oxford University Press, 1969 (retomado in: David Miller (ed.), ob. cit., pp.33-57). Veja-se também: Gerald C. MacCallum, Jr., «Negative and Positive Freedom», in: Peter Laslett, W. G. Runcinam, and Q. Skinner (eds.), Philosophy, Politics and Society, Oxford: Basil Blackwell, 1972, pp. 174-193.

${ }^{25}$ Como o escrevia Jacques Bénigne Bossuet: «Sous ce nom de liberté, les Romains se figuroient avec les Grecs un Estat où personne ne fust sujet que de la Loy, et où la Loy fust plus puissante que les hommes.» Discours sur l'histoire universelle à Monseigneur le Dauphin, Paris: Chez S. Mabre-Cramoisy, 1691, Partie III, chap. 6, p. 571. Ao longo de todo esse capítulo, Bossuet é tão insistente quanto enfático em sublinhar o sentimento e o cultivo da liberdade como traço característico da personalidade e da cultura política dos Romanos, contribuindo desse modo para o desenvolvimento de uma Romanofilia que cresce ao longo de todo o século seguinte até à Revolução de 1789.
} 
era a sua liberdade». ${ }^{26}$ Mas, segundo os diversos contextos, assim encontramos nos seus escritos o termo liberdade em qualquer das mencionadas aceções. De facto, o termo invade de tal modo os escritos políticos do filósofo que podemos dizer não haver neles tópico que seja mais insistente. Todavia, devido à sua polissemia e à grande diversidade dos contextos em que ocorre, a noção rousseauana de liberdade nada tem de convencional, apresentando-se antes de forma paradoxal, o que dá azo a interpretações diametralmente opostas do sentido e alcance da proposta política do citoyen de Genève: será ele um defensor do totalitarismo na sua forma estatista ou democratista, ou um defensor do individualismo liberal ou mesmo do libertarismo? Com efeito, se por um lado há quem o considere um expoente do individualismo extremo, que pretende eliminar todos os constrangimentos que a sociedade impõe aos indivíduos, por outro, não têm faltado também os que leem a sua filosofia política como se ela implicasse a total e incondicional subordinação do indivíduo à comunidade e a total absorção da sua vontade nos objetivos comuns ou apresentados por alguém como tais. Como são possíveis interpretações tão opostas? Deve-se isso a contradições ou ambiguidades do pensamento do filósofo, que gosta de inventar paradoxos? Ou deve-se antes à natureza do próprio problema, que talvez não admita solução definitiva, pois não se trata nele apenas de um paradoxo do pensamento, mas sim de um paradoxo realmente inscrito na própria condição social do homem?

Num estudo dedicado precisamente à conceção de liberdade em Du Contrat Social, Mathew Simpson identificou nesta obra quatro espécies de liberdade (liberdade natural, liberdade civil, liberdade democrática e liberdade moral), ao mesmo tempo que pôs em destaque a coerência do pensamento do filósofo, mostrando que muito mais fecundo do que tentar reduzi-lo a uma ou a outra forma de liberdade (daí tentando inferir ora um Rousseau “liberal”, ora um Rousseau “totalitário”, ora um Rousseau “republicano”), o que há que fazer é reconhecer e compreender a tensão fecunda que existe entre as diferentes formas de liberdade, conjugando-as em vez de as isolar e contrapor umas às outras. Segundo Simpson, essa tensão entre as diferentes formas da liberdade, que encontramos no pensamento social e político de Rousseau, revela que «o filósofo tem uma visão trágica da política e que está consciente de que todos os arranjos políticos

\footnotetext{
${ }^{26}$ CS III, XV, pp.135-136.
} 
envolvem sacrifícios significativos e que não há nenhuma ordem das coisas que seja capaz de satisfazer todos os desejos humanos.» ${ }^{27}$

O tema e o problema da liberdade são recorrentes nos escritos políticos de Rousseau, desde o Discours sur l'origine et les fondements de l'inégalité, ao Du Contrat Social, passando pelo artigo da Encyclopédie sobre Economie politique e pelo Livro $V$ de Émile. Mas também nos escritos de natureza apologética ou autobiográfica - como as Lettres écrites de la montagne, os Dialogues, as Confessions, as Rêveries - são frequentes as declarações e reflexões acerca da liberdade. Nuns e noutros encontram-se desenvolvimentos que vão no mesmo sentido, mas há também inflexões de perspetiva e dissonâncias que merecem atenção. Por certo, a honestidade hermenêutica para com o filósofo obrigar-nos-ia a ter em conta, na medida do possível, todo o inventário das suas declarações sobre o tópico que nos ocupa, por difícil que seja compatibilizá-las umas com as outras. Mas, na economia deste ensaio, só muito vagamente podemos satisfazer uma tal obrigação.

No Discours, o que sobressai é a apoteose da liberdade no estado de natureza e a inequívoca afirmação da liberdade como inerente à natureza do homem, como um dom da natureza incondicionalmente inalienável. De onde decorre a crítica aos filósofos políticos (sofistas) que tentam justificar com a natureza as formas políticas históricas de sujeição, de tirania e de escravidão. Rousseau situa-se aí na linha do mais estrito jusnaturalismo. Demos-lhe a palavra:

Da mesma forma que um cavalo selvagem indomado eriça as suas crinas, bate a terra com as patas e se debate impetuosamente à simples aproximação do cabresto, enquanto um cavalo amestrado sofre pacientemente a verga e a espora, assim o homem bárbaro não verga a sua cabeça ao jugo que o homem civilizado carrega sem murmúrio, e prefere a mais tormentosa liberdade a uma submissão tranquila. Não é, pois, pelo aviltamento dos Povos submissos que se devem julgar as

\footnotetext{
27 Mathew Simpson, Rousseau's Theory of Freedom, Continuum International Publishing Group, Ltd., London, 2007, pp. 3-4: «Rousseau did not believe that any one of them [the kinds of freedom] trumps the others, nor did he believe that some simple trade-off could resolve the tensions between them. Just as individual liberty and democracy bear a complicated relationship to one another, so do they both bear an equally complicated relationship to moral freedom, for each of these kinds of freedom is in tension with the other two. Democracies often curtail individual liberty, people who have individual liberty often lack autonomy, people who value autonomy are often suspicious of democracy, and so on. In this way, Rousseau can be said to have had a tragic view of politics, meaning that all political arrangements involve significant sacrifices and that no order of things can satisfy all of humanity's desires. His theory of freedom suggests that he was not the utopian thinker that he is sometimes made out to be.»
} 
disposições naturais do homem a favor ou contra a servidão, mas sim pelos prodígios que fizeram todos os Povos livres para se defender da opressão. Eu sei que os primeiros não fazem senão louvar sem cessar a paz e o repouso de que gozam nos seus cárceres, e que chamam paz à mais miserável servidão (miserrimam servitutem pacem appellant): mas quando eu vejo os outros sacrificar os prazeres, o repouso, a riqueza, a potência, e a própria vida à conservação do único bem, tão desdenhado por aqueles que o perderam; quando vejo os animais, que nasceram livres e que aborrecem o cativeiro, partir a cabeça contra as barras da sua prisão, quando vejo multidões de selvagens todos nus desprezar as volúpias europeias e suportar a fome, o fogo, o ferro e a morte para conservar apenas a sua independência, eu sinto que não é aos escravos que compete raciocinar acerca da liberdade. ${ }^{28}$

É dessa liberdade natural que, segundo Rousseau, decorre a liberdade política:

É, portanto, incontestável e constitui a máxima fundamental de todo o Direito Político, que os Povos deram-se a si mesmos Chefes para defender a sua liberdade e não para os subjugar. Se temos um príncipe, dizia Plínio a Trajano, é para que ele nos preserve de ter um senhor. ${ }^{29}$

O princípio metodológico assumido de «examinar os factos pelo Direito» leva o filósofo a recusar as doutrinas que defendem o estabelecimento voluntário da tirania ou a de um contrato que obrigasse apenas uma das partes e a condenar igualmente aqueles que defendem (Samuel Pufendorf é expressamente citado) que os homens podem alienar a sua liberdade, tal como o fazem com qualquer outro bem de sua propriedade. Para Rousseau, a liberdade é a mais nobre das faculdades do homem, é um dom que, tal como a vida, os homens obtêm diretamente da natureza, na sua qualidade de homens, e

\footnotetext{
${ }^{28}$ «Comme un Coursier indompté hérisse ses crins, frappe la terre du pied et se débat impétueusement à la seule approche du mords, tandis qu'un cheval dressé souffre patiemment la verge et l'éperon, l'homme barbare ne plie point sa tête au joug que l'homme civilisé porte sans murmure, et il préfère la plus orageuse liberté à un assujettissement tranquille. Ce n'est donc pas par avilissement des Peuples asservis qu'il faut juger des dispositions naturelles de l'homme pour ou contre la servitude, mais par les prodiges qu'ont fait tous les Peuples libres pour se garantir de l'oppression. Je sais que les premiers ne font que vanter sans cesse la paix et le repos dont ils jouissent dans leurs fers, et que miserrimam servitutem pacem appellant : mais quand je vois les autres sacrifier les plaisirs, le repos, la richesse, la puissance, et la vie Même à la conservation de ce seul bien si dédaigné de ceux qui l'ont perdu ; quand je vois des Animaux nés libres et abhorrant la captivité, se briser la tête contre les barreaux de leur prison, quand je vois des multitudes de Sauvages tout nuds mépriser les voluptés Européennes et braver la faim, le feu, le fer et la mort pour ne conserver que leur indépendance, je sens que ce n'est pas à des Esclaves qu'il appartient de raisonner de liberté.» Discours, pp. 110-111.

${ }^{29}$ «ll est donc incontestable, et c'est la maxime fondamentale de tout le Droit Politique, que les Peuples se sont donné des Chefs pour défendre leur liberté et non pour les asservir. Si nous avons un prince, disoit Pline a Trajan, c'est afin qu'il nous préserve d'avoir un Maître.» Ibidem.
} 
seria ofender a natureza e o autor da natureza renunciar ao mais precioso de todos os seus dons, um dom que coloca ao lado do da própria vida, pois sem liberdade a vida não é digna de ser vivida. Esta tese fundamental de antropologia filosófica não joga bem com aquela declaração posterior do filósofo, segundo a qual «não sendo um fruto de todos os climas, a liberdade não está ao alcance de todos os povos». ${ }^{30}$ No que ele parece acolher um princípio que Montesquieu retirava da sua reflexão sobre o diferente «espírito das leis» dos diferentes povos. Mas é claro que sempre se pode dizer que, nesse caso, Rousseau não fala dos povos no estado de natureza, e sim dos povos historicamente conhecidos segundo as respetivas organizações políticas, regidas que são, de facto, umas pelo princípio do despotismo, outras por princípios republicanos ou democráticos de liberdade. No Discours, porém, é inequívoca a afirmação da liberdade como prerrogativa natural do homem. E, por conseguinte, a convicção de que o estabelecimento histórico das formas de escravatura só pôde acontecer à custa de uma violência sobre a natureza do homem. É esta situação antinatural que o contrato pretende alterar, restabelecendo o homem na posse da sua liberdade. Mas há aqui vários aspetos a considerar. Em primeiro lugar, isso não acontece naturalmente: é fundado numa «convenção», num «artifício e num jogo», que supõem o exercício efetivo da liberdade de todos os indivíduos. Mas, por outro lado, a liberdade que assim é recuperada pelo contrato não é idêntica à primeira liberdade natural. Trata-se, como se dirá em Du Contrat Social, de uma nova forma de liberdade, a liberdade civil. No Discours, esse contrato ou pacto fundamental é entendido como um «contrato entre Povo e os Chefes que ele escolhe... pelo qual as duas partes se obrigam à observância das leis que aí são estipuladas e que formam os laços da sua união.» E admite-se a rutura desse contrato, em caso de violação do mesmo por parte dos Magistrados, com o consequente regresso ao estado de natureza e à primeira liberdade natural. ${ }^{31}$

Mas importa ainda ver em que consiste a suposta e celebrada liberdade de que o homem teria gozado no estado de natureza. O seu conteúdo era realmente escasso. Essa independência natural não significava a ausência de impedimentos ou obstáculos externos, resultantes por exemplo da natureza ou da própria constituição, nem era a

\footnotetext{
${ }^{30} \mathrm{CS}$, III, xv: «la liberté n'étant pas un fruit de tous les climats n'est pas à la portée de tous les peuples.»

${ }^{31}$ Discours, pp. 112 ss.
} 
possibilidade de fazer tudo o que se desejasse, mas significava apenas a não dependência da vontade dos outros. E é sobretudo esta condição que o filósofo não quer perder quando se passa à sociedade do contrato, garantindo que também aí verdadeiramente ninguém domine sobre ninguém, mas cada qual obedeça apenas à lei que a si próprio prescreve.

A solução apresentada no Discours vai sofrer pequenas mas decisivas transformações no texto de Du Contrat Social. Nesta última obra, a «ordem social» aparece logo a abrir o I capítulo como sendo «um direito sagrado, que serve de base a todos os outros»; um direito, porém, que «não vem da natureza, mas que é fundado sobre convenções». ${ }^{32} \mathrm{E}$ o contrato que instaura essa ordem e esse direito não é apresentado já como um pacto entre o povo e os seus chefes, mas como um pacto que cada indivíduo realiza ou contrata consigo mesmo, desdobrando-se na dupla qualidade de chefe-soberano e de súbdito. Só assim Rousseau pensa resolver na raiz a causa que leva à escravidão e à desigualdade, que faz de uns opressores e de outros oprimidos. Dá-se assim a completa interiorização não só do processo de instituição da sociedade, como do chefe e da instância de poder: dá-se a interiorização e subjectivização da Lei como sendo o princípio que funda a ordem e a coesão social e que se impõe a todos, mas apenas na medida em que por todos e cada um foi instituída e é assumida. Como adiante se verá, a solução não é já meramente política, mas é também, e antes de tudo, uma solução moral.

O objeto direto de um tal contrato não é o exercício do poder pelos magistrados. $O$ contrato não é, por conseguinte, um pacto de sujeição, mas um pacto de associação. $\mathrm{E}$ o princípio que funda a própria coesão social e que norteia o exercício do poder não é a pessoa do príncipe, mas a lei. É a lei, criada pela vontade unida de todos (mas no fundo por cada um solitariamente), que funda a sociedade e que legitima o poder exercido pela sociedade através dos seus magistrados.

Existe, por conseguinte, uma relação íntima entre liberdade e contrato. Mas tal relação deve considerar-se em vários níveis: antes de mais, a liberdade para contratar, que tem que ser pressuposta no homem natural (o que em Rousseau é difícil de explicar: pois como é que o homem natural pode querer sair da liberdade natural para a liberdade

\footnotetext{
32 «Mais l'ordre social est un droit sacré, qui sert de base à tous les autres. Cependant ce droit ne vient point de la nature ; il est donc fondé sur des conventions.» CS I,i, p. 41.
} 
civil, a não ser como em Hobbes ou em Locke por um cálculo de ganhos relativos?) ou no homem das sociedades históricas onde a liberdade está comprometida ou não existe; temos depois a liberdade como ato instaurador do contrato (como vontade instauradora); e, por fim, a liberdade civil ou política (a liberdade «convencional»), como a situação adquirida pelo contrato. Vejamos as palavras com que o filósofo descreve esta conquista nos caps. vii e viii do livro I do CS. São elas que constituem o cerne do nosso problema e que desde sempre deram motivo para as mais diversas interpretações do pensamento deste citoyen de Genève. O que logo começa por nos escandalizar é o facto de que o pacto que se prometia e que parecia pretender a restauração da liberdade natural perdida, resulta numa legitimação da coerção e da obediência. Na verdade, a noção de liberdade foi completamente transmutada e subvertida ao passar-se do seu significado quando aplicada ao estado de natureza para o seu uso quando aplicada ao estado de sociedade fundado pelo contrato. Escreve Rousseau:

A fim de que o pacto social não seja um vão formulário, ele encerra tacitamente este compromisso o único que pode dar força aos outros, que quem quer que recuse obedecer à vontade geral será a isso constrangido por todo o corpo: o que não significa outra coisa senão que o forçaremos a ser livre (on le forcera d'être libre), pois tal é a condição que dando cada cidadão à Pátria o garante de toda a dependência pessoal: condição que faz o artifício e o jogo da máquina política, e que somente torna legítimos os compromissos civis, os quais sem isso seriam absurdos e sujeitos aos mais enormes abusos.

No cap. viii explicita-se o balanço de ganhos e perdas resultantes da nova situação:

O que o homem perde pelo contrato social é a sua liberdade natural e um direito ilimitado a tudo aquilo que o tenta e que ele pode alcançar; o que ele ganha, é a liberdade civil e a propriedade de tudo o que possui. Para não nos enganarmos nestas compensações, é preciso distinguir bem a liberdade natural que não tem por limites senão as forças do indivíduo, da liberdade civil que é limitada pela vontade geral, e a posse que não é senão o efeito da força ou o direito do primeiro ocupante, da propriedade que não pode ser fundada a não ser num título positivo.

Não fora a intervenção da expressão «vontade geral» (volonté générale) como aquilo que funda e limita a liberdade civil, e quase poderíamos pensar que estamos a ler um passo de outro qualquer filósofo contratualista moderno, de um Hobbes ou de um 
Locke. Antes do contrato, não há lei, nem direitos determinados, nem obrigações ou deveres. Há, em contrapartida, a total independência do indivíduo em relação à vontade de qualquer outro e o indeterminado direito a tudo o que possa ser objeto da sua vontade ou desejo. Pelo contrato, porém, os indivíduos deixam de estar submetidos uns aos outros ou a um qualquer deles como seu chefe e passam a estar todos igualmente submetidos à lei comum instituída apenas pelas respetivas vontades, a qual lhes garante a determinada e efetiva usufruição dos seus direitos. A liberdade civil está, por conseguinte, limitada pelo que se poderia chamar a liberdade política da própria comunidade instituída que verdadeiramente funda, legitima e garante aquela. Há uma liberdade do corpo social (chamemos-lhe «liberdade política» à falta de outro termo) ${ }^{33}$ que é por assim dizer distinta e anterior à «liberdade civil» e é por isso que, por chocante que pareça, o filósofo pode dizer que a sociedade nascida do contrato tem o direito de «forçar a ser livre» o cidadão que lhe resiste. No mesmo capítulo viii, temos um aditamento importante para se compreender a conceção rousseauana de liberdade. Escreve aí o filósofo:

Poder-se-ia ao que precede acrescentar ao adquirido do estado civil a liberdade moral, a única que torna o homem verdadeiramente senhor de si; pois a impulsão do mero apetite é escravidão, e a obediência à lei que prescrevemos a nós próprios é liberdade (l'obéissance à la loi qu'on s'est prescrite est liberté).

Esta passagem, que parece ser apenas um apêndice ao anteriormente dito, é na verdade essencial e sem ela não entenderíamos muitos dos paradoxos e das aporias que envolvem a conceção rousseauana da liberdade. Na verdade, a liberdade civil e a liberdade política em Rousseau só se entendem se supusermos como seu fundamento uma conceção moral de liberdade, como exercício de autonomia, isto é, como poder de dar a

\footnotetext{
${ }^{33}$ Creio que é esta liberdade que Mathew Simpson identifica sob o nome de «liberdade democrática» (democratic freedom), como distinta da «civil freedom», e descreve como sendo «the collective power of the people to rule themselves» (ob.cit., p. 2). Em Rousseau não é suficientemente explícita e nomeada esta «liberdade política» (ou «liberdade democrática») como distinta da «liberdade civil», mas é da tensão entre as duas formas de liberdade que nascem os problemas de interpretação do sentido e da coerência do seu pensamento político. Há, todavia, pelo menos um caso onde o filósofo parece supor a distinção das duas formas de liberdade - a civil e a política. No cap. i do livro III de CS, onde define o que entende por governo (gouvernement): «Qu-est-ce donc que le gouvernement? Un corps intermédiaire établi entre les sujets et le souverain pour leur mutuelle correspondance, chargé de l'exécution des lois et du maintien de la liberté, tant civile que politique.»
} 
si próprio a lei a que está subordinado, sem que, todavia, isso signifique um despotismo generalizado dos indivíduos, pois antes de mais os súbditos da lei são eles próprios e não os outros.

Por conseguinte, a noção rousseauana de liberdade declina-se em vários níveis: como independência ou liberdade natural, como liberdade civil e política (convencional) e como liberdade moral, sendo esta última a que dá pleno sentido à segunda. A consideração moral da liberdade leva a estabelecer em sede de liberdade civil uma distinção qualitativa entre uma liberdade que consistisse apenas em seguir os impulsos das paixões (e que, segundo o filósofo, não seria mais do que escravidão) e a verdadeira liberdade (entendida como o ser efetivamente senhor de si, o obedecer à lei que a si próprio se dá). Esta distinção é importante para se entender a diferença entre a «vontade geral», que visa o que é comum, e a «vontade particular», que visa apenas o interesse privado dos indivíduos. Como facilmente se vê, a noção que Rousseau apresenta de liberdade civil e de liberdade política está profundamente impregnada dos pressupostos da sua antropologia moral, que mais adiante explicitaremos.

Mas há ainda um outro aspeto a considerar. Rousseau parece postular que através do contrato se passa diretamente da situação do estado de natureza para a instauração do contrato: seria o homem natural que, na sua liberdade (ainda natural), decidiria instaurar o contrato e fundar a sociedade adquirindo com ela a liberdade civil. Mas quem é esse homem natural? Trata-se de uma mera ficção, que poderá nunca ter existido? Ou o suposto verdadeiro instituidor do contrato é já o homem das sociedades históricas, que há muito se afastou do estado de natureza?

O originário contrato social - será Kant a dizê-lo sem ambiguidades - é uma mera ideia da razão, por conseguinte, uma ficção, mas por certo uma fecunda ficção racional, e não um qualquer acontecimento que alguma vez tenha ocorrido em algum momento arcaico da pré-história das sociedades humanas. ${ }^{34}$ Ele é um «acontecimento» postulado para dar razão da sociedade e da legitimidade do poder e do exercício da soberania. Também Rousseau parece ter consciência disso mesmo, quando, referindo-se às cláusulas

\footnotetext{
34 Veja-se : Immanuel Kant, Über den Gemeinspruch : das mag in der Theorie richtig sein, taugt aber nicht für die Praxis (1793), in Kants gesammelte Schriften, Akademie Ausgabe, Walter de Gruyter, Berlin, Bd. VIII, 297; Metaphysik der Sitten, Rechtslehre §47, Akademie Ausgabe, Bd. VI, 315. Sobre a interpretação kantiana de Rousseau, veja-se o meu ensaio já atrás referido: «Os ' paradoxos de Rousseau' explicados pelo Professor Kant».
} 
do contrato, diz que «ainda que elas talvez não tenham sido nunca formalmente enunciadas, são em toda a parte as mesmas, em toda a parte tacitamente admitidas e reconhecidas. ${ }^{35}$

Segundo Rousseau, a instauração voluntária da sociedade não significa uma realização da natureza em continuidade, mas representa antes uma drástica rutura com a natureza, ou antes com o assim chamado estado de natureza. Mas cabe perguntar: como é que se deu uma transformação tal no seu originário estado de natureza que levou os homens a decidirem sair dele?

No capítulo VI de Du Contrat Social o filósofo dá-nos uma resposta que pode parecer pouco convincente. Diz ele:

Eu suponho os homens chegados a um ponto em que os obstáculos que prejudicam a sua conservação no estado de natureza levam a melhor pela sua resistência sobre as forças que cada indivíduo pode empregar para se manter neste estado. Então este estado primitivo não pode mais subsistir e o género humano pereceria se não mudasse a sua maneira de ser. ${ }^{36} \mathrm{E}$ logo prossegue: «Como os homens não podem engendrar novas forças, mas apenas unir e dirigir as que existem, não têm outro meio para se conservar se não formar por agregação uma soma de forças que possa levar a melhor sobre a resistência, pondo-as em jogo em vista de um só objetivo e fazê-las agir de concerto. Esta soma de forças não pode nascer senão do concurso de vários: mas a força e a liberdade de cada homem sendo os primeiros instrumentos da sua conservação, como os comprometerá sem se prejudicar, e sem negligenciar os cuidados que deve a si mesmo? Esta dificuldade reduzida ao meu tema pode enunciar-se nestes termos: encontrar uma forma de associação que defenda e proteja com toda a força comum a pessoa e os bens de cada associado, e pela qual cada um unindo-se a todos não obedece contudo senão a si mesmo e permanece tão livre como antes. ${ }^{37}$

A saída para a sociedade do contrato é apresentada como uma solução de recurso, para evitar o pior, mas sem perder o essencial: conservar a sua pessoa e os seus bens e acima de tudo o seu bem essencial - a liberdade, a não submissão a ninguém. Também

\footnotetext{
35 «... bien qu'elles n'aient peut-être jamais été formellement énoncées, elles sont partout les mêmes, partout tacitement admises et reconnues; jusqu'à ce que, le pacte social étant violé, chacun rentre alors dans ses premiers droits et reprenne sa liberté naturelle, en perdant la liberté conventionnelle pour laquelle il y renonça.» CS I,vi, p. 51.

${ }^{36} \mathrm{CS} \mathrm{I,vi,} \mathrm{p.} 50$.

${ }^{37}$ CS I,vi, pp. 50-51.
} 
aqui Rousseau nos surpreende, pois, se seriamos levados a esperar dele que, depois de nos ter pintado tão idilicamente o estado de natureza, o que nos proporcionaria seria o mapa e o roteiro para que reencontrássemos o caminho para esse estado perdido, em contrapartida, o que ele faz é declarar uma e outra vez que a solução para a condição presente do homem passa pela completa «desnaturação do homem», convertendo-o de «homem» em «cidadão», transmutando-o totalmente de um ser da natureza em ser da sociedade. Lê-se no Émile:

Forçado a combater a natureza ou as instituições sociais, é preciso optar entre fazer um homem ou um cidadão; pois não se pode fazer ao mesmo tempo um e outro. [...] O homem natural é todo para si: é a unidade numérica, o inteiro absoluto que não tem relação senão a si mesmo ou ao seu semelhante. $O$ homem civil não é senão uma unidade fracionária que se refere ao denominador, e cujo valor está na sua relação com o inteiro, que é o corpo social. As boas instituições sociais são aquelas que melhor sabem desnaturar o homem, tirar-lhe a sua existência absoluta para ele dando-lhe uma relativa, e transportar o eu para a unidade comum; de tal modo que cada particular não se creia mais um, mas parte da unidade, e não seja mais sensível senão no todo. [... ] Aquele que na ordem civil quer conservar a primazia dos sentimentos da natureza, não sabe o que quer. Sempre em contradição consigo mesmo, sempre flutuando entre as suas tendências e os seus deveres, ele não será nunca nem homem nem cidadão. $^{38}$

Mas estas declarações chocam com outras de sentido contrário, como esta, que se encontra páginas adiante, na mesma obra:

Ó homem! recolhe a tua existência dentro de ti, e não serás mais miserável. Permanece no lugar que a natureza te atribui na cadeia dos seres, e nada te poderá fazer daí sair; não reclames contra a dura lei da necessidade, e não esgotes, a querer resistir-lhe, as forças que o céu não te deu para estender ou prolongar a tua existência, mas somente para a conservar como Ihe apraz e enquanto lhe apraz. A tua liberdade, o teu poder não se estendem senão tão longe quanto as tuas forças naturais, e não para além delas. ${ }^{39}$

\footnotetext{
${ }^{38}$ Émile, pp. 85-86.

39 Émile, ed. Garnier-Flammarion, p.98. «O homme! resserre ton existence au-dedans de toi, et tu ne seras plus misérable. Reste à la place que la nature t'assigne dans la chaine des êtres, rien ne t'en pourra faire sortir; ne regimbe point contre la dure loi de la nécessité, et n'epuise pas, à vouloir lui résister, des forces que le ciel ne t'a point données, pour étendre ou prolonger ton existence, mais seulement pour la conserver comme il lui plait et autant qu'il lui plait. Ta liberté, ton pouvoir ne s'etendent qu'aussi loin que tes forces naturelles, et pas au-delà...»
} 
Na verdade, no estado de natureza, o indivíduo era um absoluto, embora isolado e limitado; ao passo que, no estado de sociedade, ele é apenas uma parcela do todo, que encontra a sua unidade, integridade e força na comunidade do corpo social. Mas, para isso, o indivíduo tem de entregar-se todo ao corpo social, nada podendo deixar para si. A mesma ideia é desenvolvida no cap. VI do Livro I do CS: «O estado de natureza não pode mais subsistir e o género humano pereceria se não mudasse a sua maneira de ser.» ${ }^{40} \mathrm{E}$ também no cap. VII do Livro Segundo da mesma obra: «Aquele que ousa o empreendimento de instituir um povo deve sentir-se em estado de mudar por assim dizer a natureza humana.» ${ }^{41}$

Segundo as palavras de Rousseau, o indivíduo nada perde pelo contrato e «fica tão livre como antes». Mas é claro que se trata de um sofisma que joga com a ambiguidade dos termos, mediante o qual ele nos faz crer que se trata da mesma liberdade, quando é óbvio que o não é. Poderia ainda colocar-se a questão de saber se para Rousseau há alguns direitos de natureza que subsistam ou que se prolonguem na sociedade do contrato. Aparentemente, a «desnaturação» a operar implica a entrega total do indivíduo natural, incluindo a alienação da sua anterior independência ou liberdade natural. Com efeito, o filósofo fala de uma

alienação total de cada associado com todos os seus direitos a toda a comunidade, $[\ldots]$ alienação que sendo feita sem reserva, a união é tão perfeita que não possa sê-lo mais e que nenhum associado tenha algo a reclamar: porque, se restassem alguns direitos aos particulares, como não haveria nenhum superior comum que pudesse decidir entre eles e 0 público, cada um, sendo em algum ponto o seu próprio juiz, pretenderia imediatamente sê-lo em todos, o estado de natureza subsistiria e a associação tornar-se-ia necessariamente tirânica ou vã. ${ }^{42}$

Em suma: não há meio-termo: ou estado de natureza, ou estado de sociedade segundo o contrato regido pela vontade geral, a qual tem o direito de forçar os indivíduos

\footnotetext{
${ }^{40}$ CS I, vi, p. 50.

${ }^{41}$ CS II,vii, p. 77.

${ }^{42}$ "Ces clauses <du contrat> bien entendues se réduisent toutes à une seule, savoir l'aliénation totale de chaque associé avec tous ses droits à toute la communauté. [...] Et de plus, l'aliénation se faisant sans réserve, l'union est aussi parfaite qu'elle ne peut l'être et nul associé n'a plus rien à réclamer : car s'il restait quelques droits aux particuliers, comme il n'y aurait aucun supérieur commun qui pût prononcer entre eux et le public, chacun étant en quelque point son propre juge prétendrait bientôt l'être en tous, l'état de nature subsisterait et l'association deviendrait nécessairement tyrannique ou vaine.» CS I,vi, p. 51.
} 
particulares a integrar-se na ordem social e forçá-los por assim dizer a serem livres, segundo aquela liberdade que precisamente emana do contrato. Como não é viável o regresso à natureza, só resta a integração plena na sociedade.

A carta a Mirabeau, acima citada, confirma esta leitura. Mas há quem veja as coisas de outro modo, propondo uma leitura liberal de Rousseau. Neste caso, o homem natural não seria totalmente absorvido pelo cidadão do corpo social, restando ao homem natural algo de privado sobre o qual a pessoa pública do Estado não tem qualquer direito de coação. ${ }^{43} \mathrm{~A}$ desnaturalização do homem não seria então completa, o que parece contradizer a exigência de Rousseau de reconciliar completamente o homem consigo mesmo, pois instalar-se-ia então um conflito entre os homens e as leis, uma contradição permanente do homem consigo mesmo, uma divisão nele próprio, que logo se multiplica em todos os outros indivíduos do corpo social. Este seria um corpo com duas vontades potencialmente antagónicas e a «vontade geral» comum, expressa na lei, seria ineficaz perante o agregado caótico das vontades individuais que prosseguiriam sempre interesses particulares. Seria um corpo irremediavelmente dividido e em permanente contradição entre a absoluta independência das naturezas individuais e a lei comum da ordem social, e o próprio homem não saberia o que seguir, se a lei natural pré-contratual ou a lei do todo social emanada do contrato.

\section{3 - A liberdade na tensão entre «vontade geral» e «vontade particular»}

No centro da filosofia política de Rousseau e em íntima correlação com o tema da liberdade está o conceito de «vontade geral» (volonté générale), que se opõe ao de vontade particular. Num mesmo indivíduo, o filósofo supõe a existência de duas vontades em conflito: uma que decide segundo o interesse comum, que é constante, boa e justa, e que nunca erra. A outra que visa apenas o interesse particular e que, enquanto tal, é desqualificada tanto política como moralmente falando. Mas como é que se obtém a «vontade geral»? Por uma espécie de transmutação mística: de vontade da maioria em vontade geral, e de vontade geral em vontade de um só - em vontade do corpo social ou político unitário - personificado naquele que exerce a soberania (o Povo). Essa vontade

\footnotetext{
43 Veja-se no CS II, o cap. iv, sob o título «Dos limites do poder soberano», que comentarei no ponto seguinte.
} 
objetiva-se e exprime-se na Lei. E Rousseau acredita que, obedecendo à Lei em cuja confeção participou pela sua vontade (mas como e quando?), o indivíduo não obedece a ninguém, mas apenas a si próprio. Nesta abstração das vontades legisladoras particulares em Lei parece esquecer-se que se pode simplesmente dar o caso de se tratar de vontades que exprimem interesses somados dos indivíduos, os quais, organizados em grupos, impõem a sua vontade maioritária aos outros, às minorias ou aos indivíduos isolados. É claro que tal vontade maioritária seria para o filósofo uma falsa «vontade geral», pois não visa o interesse comum, mas o privado, mesmo que seja o de um grupo maioritário organizado. ${ }^{44}$ Por outro lado, Rousseau não postula a exigência da racionalidade das leis, condição que poderia funcionar como critério de correção ou de aferição da respetiva bondade, segundo critérios de objetividade. O seu anti-racionalismo conjuga-se com o seu voluntarismo, levando-o a supor que a vontade, desde que vise o que é comum (mas o que é o comum, inequivocamente falando?) é sempre reta e não se engana. A lei, em Rousseau, não é uma instituição da razão que resulte de um raciocínio racional, mas um ato espontâneo da vontade, duma vontade que integra em si a faculdade de discernimento ou de juízo (jugement), mediante a qual descobre, como que por instinto, o que é reto. ${ }^{45} \mathrm{Na}$ verdade, porém, pese embora a crença do filósofo na bondade e retidão natural da vontade, não há nada que impeça os atos desta de serem arbitrários. Sob a abstração da lei, Rousseau pode muito bem pensar que o seu citoyen não obedece a ninguém, mas simplesmente à lei em cuja feitura se presume tenha participado, e que nessa medida ele é livre. Era esta libertação que o artigo sobre «Economia Política», escrito para o Vol. V da Encyclopédie, já dizia em termos que o CS confirmará: «Mediante que arte inconcebível se pode encontrar maneira de submeter os homens para os tornar

\footnotetext{
${ }^{44}$ Sobre a natureza, qualidades e pressupostos da «vontade geral», veja-se o cap. iii do livro II do CS - «Si la volonté générale peut errer» (pp.66-67). Sobre este outro tópico nuclear e problemático do pensamento rousseauano, veja-se: António Pedro Mesquita, «Aporias da vontade geral em Jean-Jacques Rousseau», in: K. B. Basílio, Leonel R. dos Santos, M. J. Almeida (Orgs.), Jean-Jacques Rousseau: O Homem, a Obra, o Pensamento, Famalicão: Húmus, 2014, pp. 59-72.

${ }^{45}$ Émile, IV, 422 : «Quand on me demande quelle est la cause qui détermine ma volonté je demande à mon tour quelle est la cause qui détermine mon jugement : car il est clair que ces deux causes n'en font qu'une...» No CS II, iii (ed.cit, p. 66), Rousseau explica-se a respeito da retidão da «volonté générale», dizendo que ela «est toujours droite et tend toujours à l'utilité publique : mais il ne s'ensuit pas que les délibérations du peuple aient toujours la même rectitude. On veut toujours son bien, mais on ne le voit pas toujours. Jamais on ne corrompt le peuple, mais souvent on le trompe, et c'est alors seulement qu'il paraît vouloir ce qui est mal.»
} 
livres? [...] Como se pode fazer com que eles obedeçam sem que ninguém mande? Estes prodígios são obra da lei.» ${ }^{46}$

Mas, não coincidindo a «vontade geral» com a vontade de todos (quando muito sê-lo-á apenas vontade da maioria), há sempre alguns indivíduos que podem considerarse como não estando nela representados. Que fazer com eles? Será que são apenas restos irrelevantes de vontades individuais que representam interesses particulares, cuja resistência ameaça a coerência e a unidade do corpo social, e que, por conseguinte, devem ser reprimidos e forçados a obedecer à lei e assim "forçados a ser (realmente) livres"? Será que o maior número, por o ser, tem necessariamente a razão do seu lado? Sabemos que não, sobretudo quando é uma seita ou um partido organizado que leva a melhor sobre todos os outros e impõe como geral a sua vontade, que é apenas uma vontade particular generalizada. O filósofo desejaria que os seus cidadãos não tivessem nenhuma comunicação entre si e que, como mónadas isoladas e autónomas, opinassem e deliberassem por si mesmos. Só assim crê ele poder garantir que «do grande número de pequenas diferenças resultaria sempre a vontade geral e a deliberação seria sempre boa.» ${ }^{47}$ Mas, de fato, não é isso que ocorre. Não há nenhuma garantia de uma posição original liberta de preconceitos, de interesses induzidos e organizados.

Reside aqui, sem dúvida, uma das cruzes do sistema político proposto por Rousseau. Mas o filósofo não foge às dificuldades, abordando-as expressamente no cap. ii do livro IV do CS:

Como é que os oponentes são livres e submetidos a leis às quais não deram consentimento? Respondo que a questão está mal colocada. $\mathrm{O}$ cidadão consente em todas as leis, mesmo naquelas que o punem quando

\footnotetext{
${ }^{46}$ «Par quel art inconcevable a-t-on pu trouver le moyen d'assujetir les hommes pour les rendre libres ?... Comment se peut-il faire qu'ils obéissent et que personne ne commande ? Ces prodiges sont l'ouvrage de la loi.» De l'Économie Politique (in The Political Writings of Jean-Jacques Rousseau, 2 vols., ed. de C.E. Vaughan, Oxford/New York, 1962, vol. I, 245).

${ }^{47}$ «Si, quand le peuple suffisamment informé délibère, les citoyens n’avaient aucune communication entre eux, du grand nombre de petites différences résulterait toujours la volonté générale, et la délibération serait toujours bonne. [...] Enfin quand une de ces associations est si grande qu'elle l'emporte sur toutes les autres, vous n'avez plus pour résultat une somme de petites différences, mais une différence unique ; alors il n'y a plus de volonté générale, el l'avis qui l'emporte n'est qu'un avis particulier. [... ] II importe donc pour avoir bien l'énoncé de la volonté générale qu'il n'y ait pas de société partielle dans l'État et que chaque citoyen n'opine que d'après lui.» CS II, iii, pp. 66-67.
} 
ousa violar alguma delas. A vontade constante de todos os membros do Estado é a vontade geral; é por ela que eles são cidadãos e livres. ${ }^{48}$

Ou seja: para aquele que celebrou o contrato não há outra liberdade individual senão a que ele mesmo contratou consigo mesmo e que implicava deixar a sua liberdade particular para usufruir da liberdade que lhe é concedida e tornada possível pelo corpo coletivo que é emanado do mesmo contrato. É neste contexto que se deve enquadrar a passagem acima citada que justifica a coerção social e que confere legitimidade ao corpo social para "forçar os indivíduos a ser livres". O que à primeira vista parecia ser uma contradição do filósofo, revela-se antes uma exigência de coerência do cidadão consigo mesmo: ele não pode querer, ao mesmo tempo, ter as vantagens da lei coletiva, de que é (ou deve conceber-se como sendo) ele mesmo o instituidor e, quando lhe apraz, invocar a sua liberdade natural, para se furtar às exigências daquela lei que é o garante da coexistência das liberdades e de todos os direitos no seio da comunidade. As liberdades civis de cada cidadão fundam-se e têm a sua garantia na liberdade política da comunidade instituída pelo contrato.

Já por aqui se vê que não é legítimo simplificar o pensamento de Rousseau como se ele implicasse a total redução do indivíduo ao corpo social. Deve, por outro lado, ter-se em conta que há um princípio de individualismo na base da instituição social: a origem do contrato social é o interesse individual comprometido no instinto de conservação de si (igualdade, autonomia, não sujeição à vontade de outrem); o indivíduo só se abandona para se reencontrar em totalidade num modo de ser superior e o interesse social corresponderia assim ao interesse verdadeiro do indivíduo que entretanto foi completamente transmutado de homem natural em cidadão. Daí que haja intérpretes que consideram que a motivação de Rousseau permanece profundamente individualista e que a presença irredutível do indivíduo subsiste no cerne do pensamento do autor de $O$ Contrato Social. De resto, o contrato supõe que o indivíduo nele seja participante, como autor e como dando-lhe o seu acordo. Como escreve o filósofo:

\footnotetext{
48 «Comment les opposants sont-ils libres et soumis à des lois auxquelles ils n'ont pas consenti ? Je réponds que la question est mal posée. Le citoyen consent à toutes les lois, même à celles qui le punissent quand il ose en violer quelqu'une. La volonté constante de tous les membres de l'État est la volonté générale : c'est par elle qu'ils sont citoyens et libres.» CS, IV, ii.
} 
A associação civil é o ato mais voluntário do mundo; todo o homem, tendo nascido livre e senhor de si, ninguém pode sob qualquer pretexto que seja, submetê-lo sem o seu consentimento. ${ }^{49}$

Resta, porém, saber como se pode satisfazer efetivamente essa condição, tanto mais que Rousseau exige, em princípio, que ela seja exercida diretamente, e não por representantes. Como escreve:

A soberania não pode ser representada pela mesma razão que ela não pode ser alienada; ela consiste essencialmente na vontade geral, e a vontade não se representa: ela é a mesma, ou é diferente; não há meiotermo. ... Toda a lei que o povo em pessoa não ratificou é nula; pois não é uma lei. O povo inglês pensa ser livre; ele engana-se muito; não o é senão durante a eleição dos membros do parlamento; logo que eles são eleitos, ele é escravo, não é nada. Nos curtos momentos da sua liberdade, o uso que dela faz merece bem que a perca. Desde o momento que um povo se dá representantes, ele não é mais livre, ele não existe mais..$^{50}$

Será que, sempre que tal condição não seja realmente satisfeita, não existe verdadeira e legítima sociedade do contrato, e o indivíduo tem todo o direito de não se considerar submetido à lei que lhe é imposta, como se ele se mantivesse, por conseguinte, no estado de natureza?

Segundo o filósofo, o indivíduo natural é vantajosamente compensado pela sua entrada na sociedade do contrato. Não há real renúncia, nem perda, nem alienação, mas antes ganhos e uma troca vantajosa, mediante a qual se dá consistência e força ao que no estado de natureza era precário e frágil. ${ }^{51} \mathrm{~A}$ instituição social não visa perder, mas assegurar e potenciar, num novo patamar de instauração convencional, a força e a liberdade naturais de cada qual: tal o problema fundamental cuja solução o contrato visa, nas próprias palavras de Rousseau:

\footnotetext{
49 «L'association civile est l'acte du monde le plus volontaire; tout homme étant né libre et maître de luimême, nul ne peut, sous quelque prétexte que ce puisse être, l'assujettir sans son aveu.» CS, IV, ii.

${ }^{50} \mathrm{CS} \mathrm{III,} \mathrm{xv:} \mathrm{«La} \mathrm{souveraineté} \mathrm{ne} \mathrm{peut} \mathrm{être} \mathrm{représentée,} \mathrm{par} \mathrm{la} \mathrm{même} \mathrm{raison} \mathrm{qu'elle} \mathrm{ne} \mathrm{peut} \mathrm{être} \mathrm{aliénée} \mathrm{;} \mathrm{elle}$ consiste essentiellement dans la volonté générale, et la volonté ne se représente point : elle est la même, ou elle est autre ; il n'y a point de milieu. [...] Toute la loi qui le peuple en personne n'a pas ratifiée est nulle ; car n'est point une loi. Le peuple anglais pense être libre ; il se trompe fort, il ne l'est que durant l'élection des membres du parlement ; sitôt qu'ils sont élus, il est esclave, il n'est rien. Dans les courts moments de sa liberté, l'usage qu'il en fait mérite bien qu'il la perde. [...] À l'instant qu'un peuple se donne des représentants, il n'est plus libre ; il n'est plus.»

${ }^{51}$ CS, II, iv.
} 
Sendo a força e a liberdade de cada homem os primeiros instrumentos da sua conservação, como os comprometeria ele sem de prejudicar e sem negligenciar os cuidados que deve a si mesmo? Esta dificuldade, reconduzida ao meu assunto, pode enunciar-se nestes termos: Encontrar uma forma de associação que defenda e proteja com toda a força comum a pessoa e os bens de cada associado, e mediante a qual cada um unindose a todos não obedeça contudo senão a si mesmo e permaneça tão livre como antes. Tal é o problema fundamental a que o contrato social dá a solução. ${ }^{52}$

Assim, o interesse de cada indivíduo, longe de estar ausente, parece presidir à origem da sociedade do contrato; e se pode haver divergência entre o interesse dos indivíduos e o interesse geral, este último não pode nunca, numa sociedade que o seja verdadeiramente, distinguir-se do verdadeiro interesse de cada um dos indivíduos. Sem ser redutível a uma simples soma dos bens particulares, o interesse geral é totalmente absorvido pelo interesse real dos particulares. Com efeito, como diz o filósofo, «sendo o soberano formado apenas pelos particulares que o compõem, ele não tem nem pode ter interesse contrário ao deles.»1 $53 \mathrm{E}$, de resto, os compromissos que ligam os indivíduos ao corpo social apenas são obrigatórios na medida em que são mútuos e recíprocos e a sua natureza é tal que, cumprindo-os, cada qual não trabalha para os outros a não ser na precisa medida em que ao mesmo tempo trabalha para si próprio. ${ }^{54}$ É assim que, pondo em relevo estas passagens e outras do mesmo teor, se podem legitimamente surpreender em Rousseau traços de liberalismo e até de individualismo, que permitem contrariar a interpretação despótica e totalitária que também se tem feito e se pode fazer do seu pensamento. 55

No capítulo IV do Livro Segundo do CS, sob o título «Os limites do poder soberano», Rousseau explicita o seu ponto de vista das relações entre o corpo social e seus direitos como pessoa moral pública e os indivíduos enquanto cidadãos e enquanto

\footnotetext{
${ }^{52}$ «La force et la liberté de chaque homme étant les premiers instruments de sa conservation, comment les engagera-t-il sans se nuire, et sans négliger les soins qu'il se doit ? Cette difficulté ramenée à mon sujet peut s'énoncer en ces termes: 'Trouver une forme d'association qui défende et protège de toute la force commune la personne et les biens de chaque associé, et par laquelle chacun s'unissant à tous n'obéisse pourtant qu'à lui-même et reste aussi libre qu'auparavant.' Tel est le problème fondamental dont le contrat social donne la solution.» CS I, vi.

${ }^{53} \mathrm{CS}, \mathrm{I}$, vii.

${ }^{54} \mathrm{CS}, \mathrm{II}$, iv.

55 Veja-se André Vachet, L'idéologie libérale, Paris : Éditions Anthropos, p. 185; Jacky Lively and Andrew Reeve (eds.), Modern Political Theory from Hobbes to Marx, Routledege, London/ New York, 1989, pp. 111-112.
} 
pessoas privadas. A explicação e as distinções aduzidas parecem desmentir a anteriormente referida exigência de "desnaturalizar" completamente o homem. Rousseau parece manter uma distinção entre os deveres do homem enquanto cidadão e os direitos naturais que ele mantém enquanto homem privado, ao mesmo tempo que limita o poder absoluto coercivo do corpo social sobre os cidadãos àquilo que está contido no contrato ou é útil à comunidade, embora seja o soberano a julgar desta utilidade e conveniência, o que pode dar ocasião a um contencioso, que não se vê como possa ser resolvido. Escreve o filósofo:

Se o Estado ou a Cidade não é mais do que uma pessoa moral, cuja vida consiste na união dos seus membros e se o mais importante dos seus cuidados é o da sua própria conservação, é necessária uma força universal e compulsiva para mover e dispor cada parte da maneira mais conveniente ao todo. Como a natureza dá a cada homem um poder absoluto sobre todos os seus membros, o pacto social dá ao corpo político um poder absoluto sobre todos os seus e é este mesmo poder que, dirigido pela vontade geral, leva, como se disse, o nome de soberania. Mas, para além da pessoa pública, temos de considerar as pessoas privadas que a compõem, e cuja vida e liberdade são naturalmente independentes dela. Trata-se, pois, de distinguir bem os direitos respetivos dos cidadãos e do soberano, e os deveres que têm de satisfazer os primeiros na qualidade de súbditos, do direito natural de que devem usufruir na qualidade de homens. Estamos de acordo em que o que cada um aliena pelo pacto social do seu poder, dos seus bens, da sua liberdade, é apenas a parte de tudo aquilo cujo uso importa à comunidade, mas é necessário concordar também que só o soberano é juiz desta importância. Todos os serviços que um cidadão pode dar ao Estado, ele deve-os logo que o soberano os pede; mas o soberano por seu lado não pode carregar os súbditos com cadeias inúteis à comunidade; não pode sequer querer fazê-lo: pois sob a lei da razão nada se faz sem causa, da mesma forma que acontece sob a lei da natureza..$^{56}$

\footnotetext{
${ }^{56}$ «Si l'État ou la Cité n'est qu'une personne morale dont la vie consiste dans l'union de ses membres, et si le plus important de ses soins est celui de sa propre conservation, il lui faut une force universelle et compulsive pour mouvoir et disposer chaque partie de la manière la plus convenable au tout. Comme la nature donne à chaque homme un pouvoir absolu sur tous ses membres, le pacte social donne au corps politique un pouvoir absolu sur tous le siens, et c'est ce même pouvoir qui, dirigé par la volonté générale, porte $[\ldots]$ le nom de souveraineté. Mais outre la personne publique, nous avons à considérer les personnes privées qui la composent, et dont la vie et la liberté sont naturellement indépendantes d'elle. Il s'agit donc de bien distinguer les droits respectifs des citoyens et du souverain, et les devoirs qu'ont à remplir les premiers en qualité de sujets, du droit naturel dont ils doivent jouir en qualité d'hommes. On convient que tout ce que chacun aliène par le pacte social de sa puissance, de ses biens, de sa liberté, c'est seulement la partie de tout cela dont l'usage importe à la communauté, mais il faut convenir aussi que le souverain seul est juge de cette importance. Tous les services qu'un citoyen peut rendre à l'État, il les lui doit sitôt que le souverain les demande ; mais le souverain de son côté ne peut charger les sujets d'aucune chaîne inutile à la communauté ; il ne peut pas même le vouloir : car sous la loi de raison rien ne se fait sans cause, non plus que sous la loi de nature.» CS II,iv,pp. 67-68.
} 
Aqui, sim, a "lei da razão" é invocada e posta na mesma linha da "lei da natureza". Mas qual o conteúdo e forma dessa lei? A universalidade, dita sob a forma de "interesse comum"?

Na continuação, Rousseau sublinha o teor de reciprocidade que caracteriza os laços que vinculam o cidadão ao corpo social e que dão fundamento ao seu carácter obrigatório, ao mesmo tempo que, a propósito da vontade geral, diz que o que a qualifica enquanto tal não é o ser ela a expressão do número generalizado de vozes, mas sim o ser a expressão do interesse comum. Nas palavras do filósofo:

Os compromissos que nos ligam ao corpo social não são obrigatórios a não ser porque são mútuos, e a sua natureza é tal que ao cumpri-los não podemos trabalhar para outrem sem trabalhar também para si próprio. Porque é que a vontade geral é sempre reta e porque é que todos querem constantemente a felicidade de cada um deles, se não porque não há ninguém que se aproprie desta palavra cada um, e que não pensa em si mesmo ao votar para todos? O que prova que a igualdade de direito e a noção de justiça que ela produz derivam da preferência que cada um se dá e, por conseguinte, da natureza do homem, que a vontade geral para ser verdadeiramente tal, deve sê-lo tanto no seu objeto como na sua essência, que ela deve partir de todos para se aplicar a todos, e que ela perde a sua retidão natural quando tende a algum objeto individual e determinado. [...] Daí que se deve conceber que o que generaliza a vontade é menos o número das vozes do que o interesse comum que as une: porque nesta instituição cada um se submete necessariamente às condições que ele impõe aos outros; acordo admirável do interesse e da justiça que dá às deliberações comuns um carácter de equidade que se vê desaparecer na discussão de todo o assunto particular, à falta de um interesse comum que una e identifique a regra daquele que é o juiz com a daquele que é parte. ${ }^{57}$

Em suma: as condições e exigências a que deve obedecer a sociedade fundada pelo pacto social para se legitimar perante os cidadãos são tantas e de tal ordem que, no

\footnotetext{
${ }^{57}$ «Les engagements qui nous lient au corps social ne sont obligatoires que parce qu'ils sont mutuels, et leur nature est telle qu'en les remplissant on ne peut travailler pour autrui sans travailler aussi pour soi. Pourquoi la volonté générale est-elle toujours droite, et pourquoi tous veulent-ils constamment le bonheur de chacun d'eux, si ce n'est parce qu'il n'y a personne qui ne s'approprie ce mot chacun, et qui ne songe à lui-même en votant pour tous ? Ce qui prouve que l'égalité de droit et la notion de justice qu'elle produit dérivent de la préférence que chacun se donne et par conséquent de la nature de l'homme, que la volonté générale pour être vraiment telle doit l'être dans son objet ainsi que dans son essence, qu'elle doit partir de tous pour s'appliquer à tous, et qu'elle perd sa rectitude naturelle lorsqu'elle tend à quelque objet individuel et déterminé... On doit concevoir par là que ce qui généralise la volonté est moins le nombre des voix que l'intérêt commun qui les unit: car dans cette institution chacun se soumet nécessairement aux conditions qu'il impose aux autres ; accord admirable de l'intérêt et de la justice qui donne aux délibérations communes un caractère d'équité qu'on voit évanouir dans la discussion de toute affaire particulière, faute d'un intérêt commun qui unisse et identifie la règle du juge avec celle de la partie.» CS II, iv, pp. 68-70.
} 
caso de elas não serem dadas ou cumpridas efetivamente, se pode sempre perguntar se o indivíduo não pode considerar-se legitimado a reivindicar o regresso à lei do estado de natureza. Pois, se não for assim, como entender declarações de Rousseau como esta: «Toda a lei que o povo em pessoa não ratificou é nula; não é uma lei..»

\section{4 - No princípio, está a vontade: da antropo-teologia voluntarista à mitificação política da «vontade geral»}

A íntima correlação entre «vontade geral» e «liberdade» no pensamento político de Rousseau torna-se ainda mais evidente se atendermos à matriz voluntarista do pensamento do filósofo de Genebra, matriz esta que se exprime na sua antropologia, na sua teologia natural e também na sua filosofia política. Para a caracterizarmos regressemos ao Segundo Discurso. A ideia de liberdade é aí decisiva e não apenas como pressuposto de filosofia política, mas também e antes de tudo como tese fundamental de antropologia filosófica: como aquilo que faz a diferença do homem relativamente ao animal. Neste, a natureza faz tudo mediante o instinto. No homem, é ele próprio que tem de o fazer «na qualidade de agente livre». E Rousseau continua expondo a sua antropologia de cunho voluntarista:

Não é, pois, tanto o entendimento que constitui entre os animais a distinção específica do homem quanto a sua qualidade de agente livre. A Natureza manda em todo o animal e o animal obedece. O homem experimenta a mesma impressão, mas ele reconhece-se livre de aceitar ou de resistir; e é sobretudo na consciência desta liberdade que se mostra a espiritualidade da sua alma; pois a Física explica de alguma maneira o mecanismo dos sentidos e a formação das suas ideias; mas na potência de querer ou antes de escolher, e no sentimento desta potência encontramos apenas atos espirituais, que em nada são explicáveis pelas leis da Mecânica. ${ }^{59}$

\footnotetext{
${ }^{58}$ «Toute loi que le peuple en personne n'a pas ratifiée est nulle; ce n'est pas une loi.» CS III, xv, p. 134. É claro que resta a questão de saber o que significa realmente «o povo em pessoa»!

59 «Ce n'est donc pas tant l'entendement qui fait parmi les animaux la distinction spécifique de l'homme que sa qualité d'agent libre. La Nature commande à tout animal, et la Bête obéit. L'homme éprouve la même impression, mais il se reconnoît libre d'acquiescer, ou de résister ; et c'est surtout dans la conscience de cette liberté que se montre la spiritualité de son âme : car la Physique explique en quelque manière le mécanisme des sens et la formation des idées; mais dans la puissance de vouloir ou plutôt de choisir, et dans le sentiment de cette puissance on ne trouve que des actes purement spirituels, dont on n'explique rien par les Loix de la Mécanique.» Discours, pp. 56ss.
} 
Esta matriz voluntarista do pensamento de Rousseau, que se denuncia já no que se pode considerar a sua antropologia filosófica exposta no Discours, é congruente com a teologia natural que se expõe na Parte IV do Émile e, em última instância, é ela que explica também a doutrina da «vontade geral» em torno da qual gira a filosofia política exposta em 0 Contrato Social. ${ }^{60}$ Para compreendermos esse estrato mais fundo do pensamento do filósofo genebrino, devemos atender àquela peça que leva por título «Profissão de Fé do Vigário de Sabóia». Aí deparamos com esta tese fundamental da filosofia primeira - ou da onto-teologia - de Rousseau: No começo, está uma vontade:

Todo o movimento que não é produzido por um outro, não pode vir a não ser de um ato espontâneo, voluntário; como os corpos inanimados não agem, senão pelo movimento, não existe verdadeira ação sem vontade. Eis o meu primeiro princípio. Eu creio, pois, que uma vontade move o universo e anima a natureza. ${ }^{61}$

Ao mesmo tempo que vai expondo a sua teologia natural, explicitando o seu dogma fundamental, Rousseau faz-nos perceber que, da mesma maneira que a máquina do mundo foi criada e posta em movimento por um ato de vontade, assim também a máquina do corpo político pode ser criada e posta em movimento por um ato das vontades reunidas dos seres humanos cuja principal e distintiva prerrogativa é a vontade. A criação do corpo político mimetiza a criação do corpo do mundo. ${ }^{62}$ De facto, o Vigário de Sabóia, a quem Rousseau confia a exposição da sua teologia natural, acaba também por confessar a sua tese da antropologia voluntarista, na linha do que já conhecemos do Discurso: o que caracteriza os movimentos humanos propriamente tais é o seu carácter espontâneo e voluntário. Ora, essa causa de movimento livre e espontâneo não existe na matéria, a qual só se move se for movida por outra coisa. Já sabíamos pelo Discours que é

\footnotetext{
${ }^{60}$ A nossa tese, segundo a qual a chave para decifrar a doutrina política do Contrat Social se deve procurar na antropologia teológica exposta no Émile, encontra-se com a de Martin Rang, exposta na sua obra Rousseaus Lehre vom Menschen, Göttingen, 1959, p. 07-08.

${ }^{61}$ «Je crois donc qu'une volonté meut l'univers et anime la nature.»Émile, p. 412.

62 Já Hobbes - também ele um voluntarista - fizera algo parecido no seu Leviathan ao estabelecer uma analogia entre o Fiat da criação divina do mundo e do homem e o fiat que cria a civitas ou a Commonwealth humana. Veja-se o meu ensaio «Hobbes e as metáforas do Estado», in: Leonel Ribeiro dos Santos, O espírito da letra. Ensaios de hermenêutica da Modernidade, Imprensa Nacional-Casa da Moeda, Lisboa, 2007. Não é esse, porém, o único traço comum entre Rousseau e Hobbes: o «Discours sur l'Économie Politique» (1755: Oeuvres Complètes, III, p. 244) desenvolve uma analogia entre o corpo do Estado e um corpo orgânico que constitui a réplica à analogia entre o corpo mecânico do Estado e o corpo natural com a qual Hobbes abre o seu Leviathan.
} 
a liberdade da vontade, e não a razão, o atributo que melhor dá testemunho da condição espiritual do homem. Mas o que nesse IV livro de Émile é novo é o facto de que essa antropologia voluntarista é posta em íntima correlação com uma teologia voluntarista: para explicar o mundo, prossegue Rousseau pela voz do seu Vigário, não tenho que pressupor uma suprema razão inteligente, mas «remontar a alguma vontade como sua primeira causa». E, na mesma linha, o seu terceiro artigo de fé será então o de que «o homem é livre nas suas ações» e «se o homem é ativo e livre, ele age por si mesmo». ${ }^{63}$ Trata-se de uma evidência de experiência íntima, que em nada é diminuída pelo facto de não se saber qual seja a natureza dessa vontade. $\mathrm{E}$ isso vale tanto para a vontade de Deus como para a dos homens: «A vontade é-me conhecida pelos seus atos, não pela sua natureza.» ${ }^{64}$

Temos assim estabelecido - por um intuitivismo fáctico (ou uma evidência intuitiva fáctica) - o primado da vontade: há uma vontade arquetípica, divina, instauradora da ordem da natureza, da qual decorre também a qualificação da vontade do homem, maximamente potenciada quando é a vontade unida de todos, sob a forma de volonté générale que instaura a ordem social. Desse pressuposto ou princípio fundamental seguem-se, como se fossem evidências naturais do sentimento, a originária bondade e retidão da vontade, o seu carácter absoluto e infalível, por fim, a absoluta confiança na vontade geral. A vontade geral dos indivíduos, ao instaurar a ordem social na qual a subsistência dos indivíduos particulares ganha consistência e pertinência, imita a vontade de Deus que cria e põe a máquina do mundo em movimento e instaura a ordem da natureza. Compreendemos agora a sacralização da ordem social que se diz logo no primeiro capítulo do CS. Dela decorre, como vimos, o carácter constringente da ordem social sobre os indivíduos. Mas tratando-se de uma ordem convencional e artificial, dependente que está do poder absoluto da vontade, na sua instituição e na sua manutenção, disso resulta também o seu carácter contingente. A ordem social, não tendo uma base natural, depende apenas da vontade do soberano (o conjunto dos indivíduos eventualmente agregados em torno de um objetivo de interesse e utilidade comuns), o qual não pode dar-se nenhum limite em relação ao futuro e que, por isso

\footnotetext{
${ }^{63}$ «L'homme est donc libre dans ses actions... c'est mon troisième article de foi. [... ] Si l'homme est actif et libre, il agit de lui-même». Émile, pp. 422-423.

${ }^{64}$ Émile, p. 412.
} 
mesmo, tanto pode reiterar como revogar, quando lhe aprouver e num sentido ou noutro, a instauração da sociedade. Rousseau está bem consciente da essencial fragilidade da sua vontade geral como princípio inalienável da soberania. O que a absolutiza e lhe dá força é igualmente o que a relativiza e a fragiliza. ${ }^{65}$

Uma e outra vez, tentando explicar o seu conceito de liberdade, Rousseau insiste em dizer que liberdade não é fazer o que apraz ao indivíduo ou o que ele quer, mas significa o não estar dependente da vontade de outro, o que implica que também não deve subordinar os outros à sua vontade. Se a independência natural consiste em agir como apraz a cada um sem respeito pelos outros, a liberdade civil e política é a capacidade para agir de acordo com regras auto-prescritas que respeitam os direitos dos outros. A liberdade, entendida como mera independência, é basicamente egoísta, tendo por critério o amor-próprio e está propensa a gerar conflitos entre os indivíduos. Em contrapartida, a liberdade num sentido civil é a que o indivíduo exerce quando age por regras auto-prescritas que são compatíveis com as que regem as ações dos outros. Esta liberdade supõe não já a independência, mas a autonomia, o ser dono de si, das suas ações e do princípio que as rege, mormente na relação com os outros. É neste sentido que, se o indivíduo não se força a si mesmo a ser livre (civil e moralmente falando), então o corpo social, para subsistir, tem o direito de o forçar a ser livre, não no sentido da independência natural e da satisfação dos seus interesses pessoais, mas no sentido de o constranger a usufruir daquela liberdade civil que torna possível a satisfação dos direitos e garantias que ele aufere pela pertença ao corpo social e para cuja instituição foi tido em conta. O que é que pode garantir que as regras auto-prescritas por um indivíduo não entram em conflito com as regras auto-prescritas por outros membros da sociedade? O filósofo pressupõe que o acordo se dá espontaneamente desde que os indivíduos, no seu querer, queiram o que é do interesse comum e não o que é do respetivo interesse privado. Disso resulta o «corpo moral e coletivo», como uma espécie de entidade mística, dotada de «um eu comum», na qual «cada um de nós coloca a sua pessoa e todo o seu poder sob a suprema direção da vontade geral; e em troca recebe cada membro como uma indivisível parte do todo.» 66

\footnotetext{
${ }^{65} \mathrm{CS}$, pp. 63-64.

${ }^{66} \mathrm{CS}$ I,vi, pp. 51-52.
} 
Está assim pressuposta uma lógica de completa reciprocidade: o que eu faço, fazem-no todos os outros; eu dou e, no mesmo ato em que o faço, recebo de todos. O eu coletivo emerge quando os associados se entregam a si mesmos e todos os seus direitos à comunidade com vista a preservar e a promover o bem comum e o bem-estar geral. Esta vontade geral do eu coletivo quer a sua preservação e, por isso, constrange os indivíduos a manterem-se nas leis que eles próprios criaram. O eu moral coletivo - a vontade geral - é um produto da vontade unida dos cidadãos, na medida em que cada qual aspira ao bem e interesse comum e nesse sentido ela é apenas uma extensão dessas vontades individuais enquanto elas visam o que é geral e comum, a ordem que garante a coexistência das liberdades, que as possibilita no mesmo lance em que as limita. Quando, porém, os cidadãos pretendem levar por diante apenas os seus interesses privados, eles entram em contradição consigo mesmos enquanto instituidores do contrato, muito antes de entrarem em contradição com o todo social. «Forçá-los a ser livres» é, então, mediante a lei de que eles são supostos co-autores, constrangê-los a agir de acordo com eles mesmos e com a vontade geral, a qual precisamente, de acordo com as condições do contrato, lhes garante a conservação da sua vida e a liberdade civil, juntamente com o gozo dos seus direitos de igualdade e da sua propriedade, em segurança.

Para concluir, diria que as principais dificuldades que envolvem a noção de liberdade na obra de Rousseau, e que explicam muitos dos seus paradoxos, resultam de dois pressupostos fundamentais do pensamento do filósofo, que, de resto, se conjugam nos seus efeitos teóricos e práticos.

Em primeiro lugar, da sua recusa em admitir alguma continuidade entre a natureza e a instituição social, que permitisse pensar a relação de ambas sob a forma de uma troca e tensão permanentes, troca e tensão produtoras de energias sociais, em que a seiva da natureza (ou do que por tal se nomeie) alimentasse e regenerasse a máquina artificial e convencional da instituição política. Ao não consentir a permeabilidade entre a natureza e a ordem política, Rousseau passa da absolutização idealizada e mítica da primeira, no Discurso sobre a origem da desigualdade, para a idealização mística da segunda, em 0 Contrato Social, atribuindo o primado à instauração da ordem política segundo os princípios do contrato social como a forma que resta para se operar a redenção e salvação coletiva do homem, por iniciativa e obra dos próprios homens. Numa palavra, se 
a origem do mal é social, a sua solução também tem de sê-lo. ${ }^{67}$ O Estado, o corpo político, ganha assim uma feição que não é meramente instrumental ou funcional, de gestão das coisas públicas e comuns, mas é-lhe atribuída uma essência quase transcendente, sendo concebido como uma comunidade ético-política que exige por inteiro não só os corpos, mas também as almas dos que dela fazem parte. O corpo político é uma espécie de corpo místico, com a sua «religião civil» e a sua «teologia civil». ${ }^{68}$ Daí as portas que se abrem para a absolutização do coletivo, para o totalitarismo, ou mesmo para todas as formas políticas de terror da liberdade ou da virtude exercidas por aqueles que se arrogam como os legítimos intérpretes e executores da vontade do corpo social.

Em segundo lugar, do seu voluntarismo radical, que se expõe nos domínios essenciais da sua conceção filosófica, da teologia natural à antropologia e à filosofia política, e que faz com que a sua conceção da liberdade política e civil seja determinada por uma conceção filosófica e moral da liberdade e da política, muito mais do que ele possa ter imaginado. E é assim que, resultando embora de interpretações de sentido contrário, as críticas de Benjamin Constant e de Hannah Arendt à conceção rousseauana de liberdade encontram-se e de algum modo mutuamente se neutralizam. Pois, segundo Constant, a conceção de liberdade de Rousseau não está em consonância com a liberdade individualista dos Modernos e antes propõe um regresso anacrónico à liberdade dos Antigos. ${ }^{69}$ Mas, ao mesmo tempo, ao pensar a liberdade sob a forma da autonomia da vontade e da soberania do eu individual ou coletivo, o filósofo genebrino revela, segundo Arendt, um fundo teológico e cristão, que entronca antes na tradição do voluntarismo agostiniano dos Medievais (e talvez também no voluntarismo e pragmatismo dos Romanos!) e do nominalismo e individualismo dos Modernos e atingirá a sua máxima expressão no idealismo da liberdade de filósofos alemães como Kant,

\footnotetext{
${ }^{67}$ Esta tese foi avançada por Ernst Cassirer, na sua obra Das Problem Jean-Jacques Rousseau (1932: trad. ingl.: The Question of Jean-Jacques Rousseau, New York, 1954, pp. 75 ss) e tem tido seguidores mais recentes. Veja-se: Otto Vossler, Rousseaus Freiheitslehre, Göttingen: Vandenhoeck \& Ruprecht, 1963; Sergio Cotta, «La position du problème de la politique chez Rousseau», in : Études sur le Contrat Social de Jean-Jacques Rousseau, Paris, 1964, pp. 177-190 ; Lucio Coletti, From Rousseau to Lenin. Studies in Ideology and Society, NLB, London, 1972, pp. 144-149 (ed. italiana : Ideologia e Società, Laterza, Bari/Roma, 1969).

${ }^{68}$ CS IV, viii, p. 179.

${ }^{69}$ Veja-se : «De la liberté des Anciens comparée à celle des Modernes», in : Idem, Écrits politiques, pp. 589619.
} 
Fichte, Schelling, Hegel e Schopenhauer. ${ }^{70} \mathrm{~A}$ ideia de liberdade, que se expõe na obra de Rousseau, não seria, pois, comodamente redutível nem à dos Antigos nem à dos Modernos, pois por ela passa também a seiva da liberdade entendida como a divina potentia absoluta, tal como a pensaram os teólogos e filósofos Medievais e Protomodernos.

$7^{70}$ Veja-se : Hannah Arendt, «Qu'est-ce que la liberté ?», in Idem, La crise de la culture, Paris : Gallimard, 1961, pp. 213-214. 


\section{Referências}

ARENDT, Hannah. Qu'est-ce que la liberté?, In: ARENDT, Hannah, La crise de la culture, Paris: Gallimard, 1961.

BERLIN, Isaiah. Two concepts of liberty. In: BERLIN, Isaiah. Four essays on liberty. Oxford: Oxford University Press, 1969 p. 33-57. (Retomado em David Miller (ed.))

BOSSUET, Jacques Benigne. Discours sur l'histoire universelle à Monseigneur la Dauphin. Paris: Chez S. Mabre-Cramoisy, 1691, Partie III, chap. 6, p.571.

CASSIRER, Ernst. Das Problem Jean-Jacques Rousseau. In: Archiv für Geschichte der Philosophie, 41 (3), 1932, pp.479-513. Trad. inglesa por P. Gay: The Question of JeanJacques Rousseau. New York: Columbia University Press, 1954.

CHAPMAN, John W. Rousseau - Totalitarian or Liberal?. New York: Columbia University Press, 1956.

COLETTI, Lucio. From Rousseau to Lenin: studies in ideology and society. London: NLB, 1972 (Ed. original italiana: Ideologia e Società, Bari/Roma: Laterza, 1969).

CONSTANT, Benjamin. De l'esprit de conquête et de l'usurpation dans leurs rapports avec la civilisation européenne (1814), In: CONSTANT, Benjamin. Écrits politiques,

Paris:Gallimard,1997.

CONSTANT, Benjamin. De la liberté des Anciens comparée à celle des Modernes. In:

CONSTANT, Benjamin. Écrits politiques, Paris : Gallimard, 1997, p. 589-619.

COTTA, Sergio. La position du problème de la politique chez Rousseau. In: COTTA, Sergio. Études sur le contrat social de Jean-Jacques Rousseau. Paris: Societé des Belles Lettres, 1964 .

KANT, Immanuel. Über den Gemeinspruch: das mag in der Theorie richtig zu sein, taugt aber nicht für die Praxis. In : Kants gesammelte Schriften, Akademie Ausgabe, Band VIII. Berlin: Walter de Gruyter, 1912.

KANT, Immanuel. Vorlesungen über Anthropologie. In: Kants gesammelte Schriften: Bd. 25.2, Akademie Ausgabe. Berlin: Walter de Gruyter, 1997.

KRYGER, Edna. La notion de liberté chez Rousseau et ses répercussions sur Kant. Paris: Lib. A. G. Nizet, 1979.

KUKATHAS, Chandran. Liberty. In: Robert E. Goodin and Philipp Pettit (Eds.), A Companion to contemporary political philosophy. Oxford / Cambridge Ms.: Blackwell, 1993. p. 534-547. 
LIVELY, Jacky; REEVE, Andrew (Eds.). Modern political theory from Hobbes to Marx. London /New York: Routledge, 1989.

MacCALLUM Jr., Gerald C. Negative and Positive Freedom. In: RUNCINAM, Peter; LASLETT, W. G.; SKINNER, Quentin (Eds.). Philosophy, politics and society, Oxford: Basil Blackwell, 1972. p. 174-193.

MESQUITA, António Pedro. Aporias da vontade geral em Jean-Jacques Rousseau. In: BASÍLIO, K. B.; SANTOS, Leonel R. dos; ALMEIDA, M. J. (Orgs.). Jean-Jacques Rousseau: o homem, a obra, o pensamento. Famalicão: CEC/Editorial Húmus. 2014. p. 59-72.

MILLER, David (Ed.). Liberty. Oxford: Oxford University Press, 1991. p. 183-205.

PLAMENATZ, John. Ce qui ne signifie autre chose sinon qu'on le forcera d'être libre. In: PETERS, Richard; CRANSTON, M. (Eds.). Hobbes and Rousseau: a collection of critical essays, New York: Anchor Books, 1991.

RANG, Martin. Rousseaus Lehre vom Menschen, Göttingen: Vandenhoeck \& Ruprecht, 1959.

ROUSSEAU, Jean-Jacques. Correspondance complète : vol. 21. Ed. Ralph A. Leigh. Oxford: Voltaire Foundation, 2004.

ROUSSEAU, Jean-Jacques. Discours sur l'origine et les fondements de l'inégalité. Paris: Gallimard, 1965.

ROUSSEAU, Jean-Jacques. Du contrat social. Paris: Garnier-Flammaron, 1966.

ROUSSEAU, Jean-Jacques. Émile ou de l'éducation. Texte établi par Charles Wirz, présenté et annoté par Pierre Burgelin. Paris: Gallimard, 1969.

ROUSSEAU, Jean-Jacques. Émile ou de l'éducation, Paris : Garnier-Flammarion,

ROUSSEAU, Jean-Jacques. Les rêveries du promeneur solitaire. Paris: GarnierFlammarion, 1964.

ROUSSEAU, Jean-Jacques. Lettre à Monsieur le Marquis de Mirabeau. In: ROUSSEAU, Jean-Jacques, Collection complète des oeuvres. Genève: Du Peyrou / Moultou, 17801789, vol. 12 (1782). p.160-164. Disponivel em: http://www.rousseauonline.ch/Text/lettre-amonsieur-le-marquis-de-mirabeau.php). Acesso em 7 de outubro 2017.

ROUSSEAU, Jean-Jacques. Oeuvres complètes, vols.. III e IV, Paris: Gallimard : Bibliothèque de la Pléiade, 1964 e 1969.

ROUSSEAU, Jean-Jacques. The political writings of J.-J. Rousseau, 2 vol. Ed. de C. E. Vaughan. Oxford / New York: John W. \& Sons, 1962 ( $1^{\mathrm{a}}$ ed. Cambridge: Cambridge University Press, 1915). SANTOS, Leonel Ribeiro dos. Os paradoxos de Rousseau 
explicados pelo Professor Kant. In: BASÍLIO Kelly B., SANTOS, Leonel Ribeiro dos, ALMEIDA Maria João (Orgs.), Jean-Jacques Rousseau: o homem, a obra, o pensamento. Famalicão: CEC/Editorial Húmus, 2014, pp. 25-48.

SANTOS, Leonel Ribeiro dos. A Ideia de Liberdade no Pensamento de Rousseau. In: LEAL, Ernesto Castro (Org.), República e Liberdade, Lisboa: CHUL, 2011, pp. 149-179.

SKINNER, Quentin. The paradoxes of political liberty. In: MILLER, David (Ed.), Liberty. Oxford: Oxford University Press, 1991. p. 183-205.

SIMPSON, Mathew. Rousseau's theory of Freedom. London: Continuum International Publishing Group, Ltda., 2007.

TALMON, Jacob L., The origins of totalitarian democracy. London: Secker \& Warburg, 1952.

VACHET, André. L’idéologie libérale: l'individu et sa propriété. Paris: Anthropos, 1970.

VOSSLER, Otto. Rousseaus Freiheitslehre. Göttingen: Vandenhoeck \& Ruprecht, 1963.

Recebido em: 13/12/2016 Aprovado em: 09/03/2017

Universidade do Estado de Santa Catarina - UDESC Programa de Pós-Graduação em Educação - PPGE Revista Linhas

Volume 18 - Número 38 - Ano 2017 revistalinhas@gmail.com 